PONTIFÍCIA UNIVERSIDADE CATÓLICA DO RIO DE JANEIRO

O Efeito da Operação Lava Jato nas Empresas
Investigadas
O Caso da Andrade Gutierrez

Martina Fuchshuber de Araújo Jorge

Trabalho de Conclusão de Curso

Centro de Ciências sociais - CCS

Departamento de Administração

Graduação em Administração de Empresas 
Martina Fuchshuber de Araújo Jorge

\section{O Efeito da Operação Lava Jato nas Empresas Investigadas O Caso da Andrade Gutierrez}

Trabalho de Conclusão de Curso

Trabalho de Conclusão de Curso, apresentado ao programa de graduação em Administração da PUC-Rio como requisito parcial para a obtenção do título de graduação em Administração.

Orientadora: Liana Ribeiro dos Santos

Rio de Janeiro

Novembro de 2018 


\section{Agradecimentos}

Gostaria de agradecer à minha família, mas em especial à minha mãe, Mônica, por sempre ter me apoiado e motivado durante todos os meus anos de escola e faculdade. Por ter acreditado em mim, e, ainda, por ter me proporcionado uma educação que me formou não apenas como profissional, mas também como ser humano.

Além disso, gostaria de agradecer também ao meu namorado, por estar sempre ao meu lado, mesmo nos momentos difíceis, por ter sido bastante paciente nesses últimos meses e ter colaborado com o resultado final desse trabalho.

A todos os meus amigos, dentro e fora da PUC, que de alguma forma contribuíram para que eu pudesse chegar onde estou hoje.

E, por fim, gostaria de agradecer à minha orientadora, Liana Ribeiro, por me guiar na elaboração desse estudo e pelas opiniões, avaliações e comprometimento com o resultado final. 


\section{Resumo}

Jorge, Martina. O Efeito da Operação Lava Jato nas Empresas Investigadas. Rio de Janeiro, 2018. 47 p. Trabalho de Conclusão de Curso - Departamento de Administração. Pontifícia Universidade Católica do Rio de Janeiro.

O presente estudo teve como objetivo principal entender se a Operação Lava Jato, grande investigação de esquema de corrupção e lavagem de dinheiro, teve impacto no desempenho e, consequentemente, nos indicadores financeiros de uma empresa investigada, tendo sido selecionada para essa pesquisa a Andrade Gutierrez. Foram analisados os demonstrativos financeiros dos anos de 2012 a 2017, para ter um panorama de dois anos anteriores (2012 e 2013) à Operação - deflagrada em 2014 - e quatro anos durante a investigação (2014, 2015, 2016 e 2017). Para isso, foram feitas análises vertical e horizontal dos Balanços e DREs da empresa e calculados os indicadores de Liquidez, Estrutura de Capital, Rentabilidade e Lucratividade e, ainda, o fator de insolvência da empreiteira. Ao fim do estudo, concluiu-se que o envolvimento da companhia no escândalo teve sim consequência em seu desempenho financeiro e que seus indicadores apresentaram significativas pioras nos anos de 2014 - ano de início da operação - e 2016, ano em que o ex-presidente da Andrade Gutierrez foi preso.

Palavras- chave

Operação Lava Jato, Andrade Gutierrez, Análise Financeira, Liquidez, Rentabilidade, Estrutura de Capital, Fator de Insolvência 


\section{Abstract}

Jorge, Martina. The Effect of the Operation 'Lava Jato' in the Companies Investigated The Case of Andrade Gutierrez. Rio de Janeiro, 2018. 47 p. Trabalho de Conclusão de Curso - Departamento de Administração. Pontifícia Universidade Católica do Rio de Janeiro.

The purpose of this research is to understand if the Operation 'Lava Jato', a big investigation of corruption in Brazil, had any impact at the performance and, therefore, at the financial ratios of a company under investigation, and for that the company Andrade Gutierrez was selected. The financial statements from 2012 to 2017 were analysed, because it was interesting to have the image of the organisation of two years before the beginning of the Operation (2012 and 2013) and four years during it (2014, 2015, 2016 and 2017). For this, vertical and horizontal analysis of the Balance Sheet and the Income Statement were made and ratios of profitability, capital structure, liquidity and the insolvency factor of Kanitz were calculated. At the end of the research, it was possible to conclude that the participation of the company in the scandal had an influence on its financial performance, and that its financial ratios had significant decrease in 2014 - year of the beginning of the Operation 'Lava Jato' and 2016, when the former CEO of Andrade Gutierrez was arrested.

Key-words

Andrade Gutierrez, liquidity, profitability, insolvency factor, capital structure, financial analysis 


\section{Sumário}

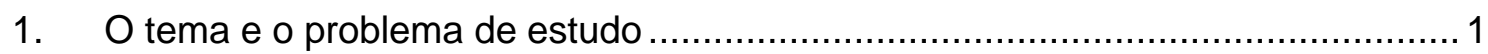

1.1. Introdução ao tema e ao problema de estudo ........................................... 1

1.2. Objetivo do estudo ....................................................................... 2

1.3. Objetivos intermediários do estudo ….............................................. 2

1.4. Delimitação do estudo....................................................................... 2

1.5. Justificativa e relevância do estudo ....................................................... 3

2. Referencial Teórico .......................................................................................... 4

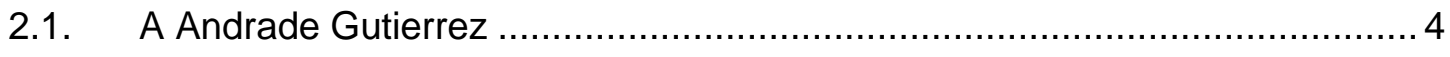

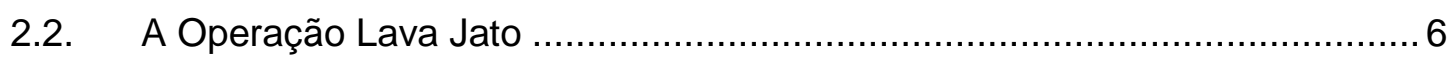

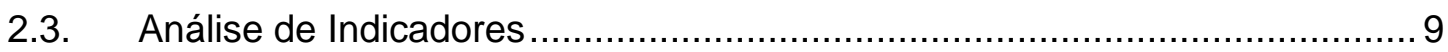

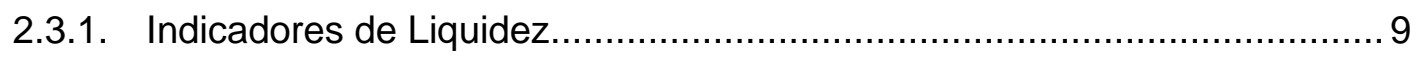

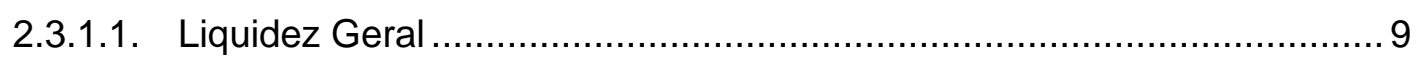

2.3.2. Indicadores de Rentabilidade e Lucratividade ..................................... 10

2.3.3. Indicadores de Estrutura de Capital.................................................. 11

2.3.3.1. Participação de Capitais de Terceiros .............................................. 12

2.3.4. Fator de Insolvência ......................................................................... 13

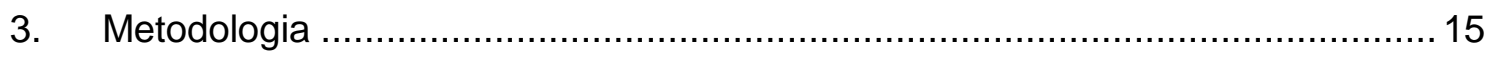

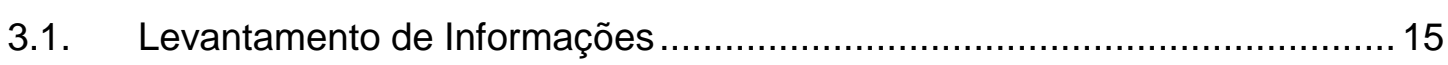

3.2. Limitações do Estudo ....................................................................... 15

4. Apresentação e Análise dos Resultados .................................................... 17

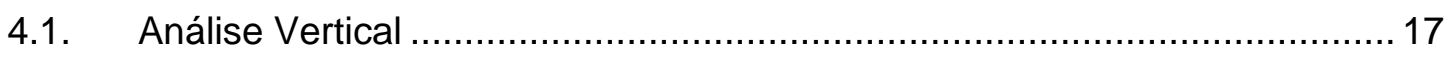

4.2. Análise Horizontal ......................................................................... 18

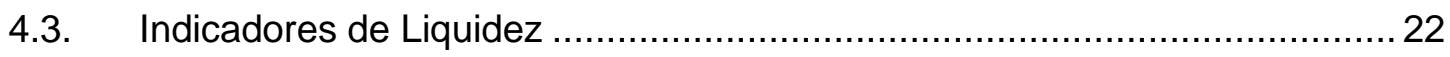

4.4. Indicadores de Rentabilidade e Lucratividade ........................................ 23

4.5. Indicadores de Estrutura de Capital ...................................................... 25

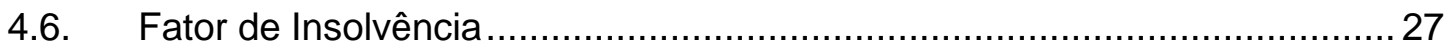

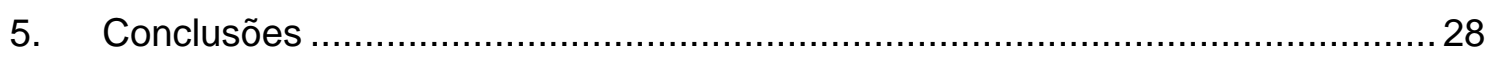

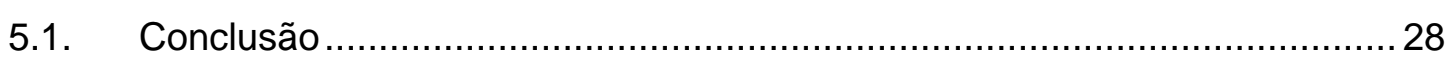

5.2. Sugestão e recomendação para novos estudos........................................ 29

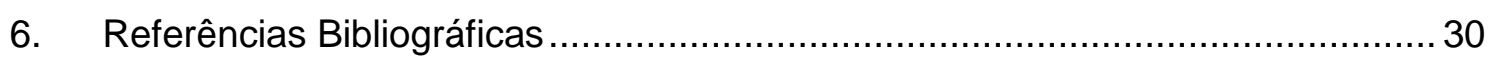

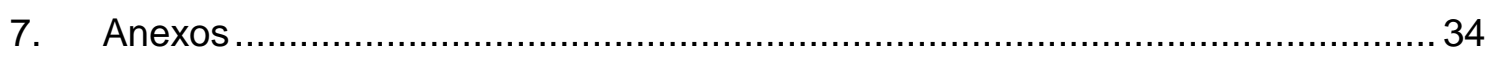

7.1. Balanço Patrimonial Andrade Gutierrez 2012, 2013 e 2014 ...................... 34

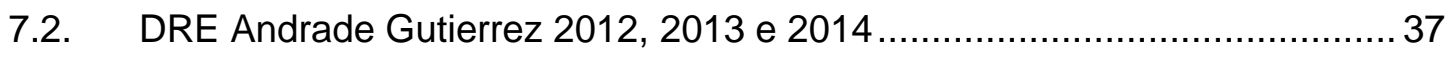

7.3. Balanço Patrimonial Andrade Gutierrez 2015, 2016 e 2017 ....................... 38

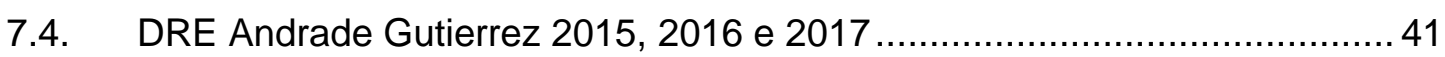


7.5. Balanço Patrimonial Queiroz Galvão 2012 e 2013 42

7.6. DRE Queiroz Galvão 2012 e 2013 46

\section{Lista de Figuras}

Figura 1 - Arena de Amazônia ............................................................................. 5

Figura 2- Estrutura de participações da Andrade Gutierrez Participações .................... 6

Figura 3 - Como Funcionada a Operação Lava Jato............................................ 8

Figura 4- Termômetro de Insolvência .............................................................. 14

Figura 5 - Termômetro de Kanitz da \Andrade Gutierrez.........................................2

\section{Lista de Tabelas}

Tabela 1 - Análise Vertical do Ativo.................................................................... 17

Tabela 2 - Análise Vertical do Passivo e Patrimônio Líquido .................................... 17

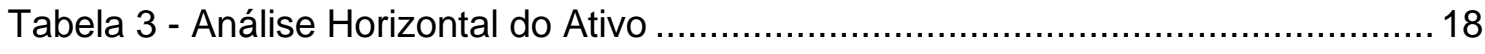

Tabela 4 - Análise Horizontal do Passivo e Patrimônio Líquido .................................. 19

Tabela 5 - Análise Horizontal do DRE.............................................................. 21

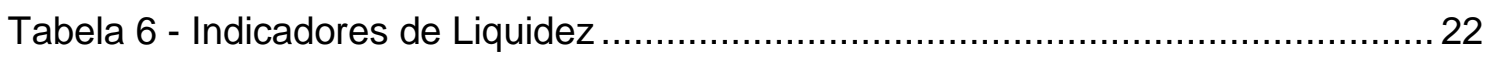

Tabela 7 - Indicadores de Rentabilidade e Lucratividade ............................................ 23

Tabela 8 - Indicadores de Rentabilidade e Lucratividade da Queiroz Galvão ..............24

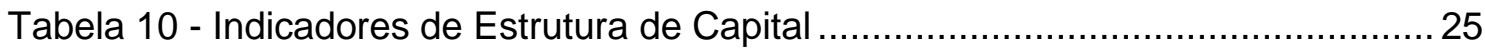

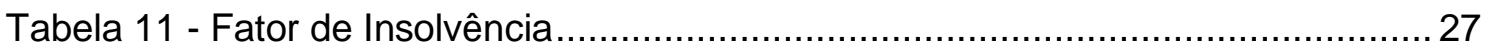

\section{Lista de Gráficos}

Gráfico 1 - Relação Lucro Líquido e Resultado de Equivalência Patrimonial 29 


\section{O tema e o problema de estudo}

\subsection{Introdução ao tema e ao problema de estudo}

Em março de 2014, a Polícia Federal brasileira deu início a uma das maiores operações investigativas do país. Esta começou pela análise de um posto de gasolina em Brasília - de onde veio o nome da operação "Lava Jato" - por suspeita de lavagem de dinheiro (UOL Notícias, 2017) e acabou se desdobrando em uma busca que foi além de seu objetivo inicial, se transformando na maior investigação de corrupção da história do país.

Durante a $7^{a}$ fase da Lava Jato, deflagrada em novembro de 2014 e batizada de "Juízo Final" a Polícia Federal passou a investigar grandes empreiteiras, entre elas a Odebrecht, a Camargo Correa e a Andrade Gutierrez, entre outras, (Época, 2015) sob suspeita de formação de cartel, desvio de recursos públicos e pagamento de propina ( $G 1,2015)$. Com o desenvolvimento da operação, descobriu-se que a empreiteira era parte de um cartel de empresas que realizavam pagamento de propinas por meio de contas no exterior para obter vantagens em contratos, sobretudo envolvendo a maior petrolífera brasileira, a Petrobras, e obras públicas, como as realizadas para Copa do Mundo de 2014 e as Olimpíadas do Rio de 2016. (TERRA, 2016).

Após os escândalos supracitados, o então presidente da Andrade Gutierrez (AG), Otávio Marques de Azevedo, foi condenado à prisão domiciliar em fevereiro de 2016 e condenado definitivamente à prisão em regime fechado em setembro do mesmo ano, após ter sua pena atenuada por colaborar com as investigações por meio da delação premiada $(G 1,2016)$ acordo firmado com o Ministério Público onde o réu colabora com as investigações em troca de benefício.

Neste mesmo ano, a AG publicou um pedido de desculpas à sociedade brasileira, no qual se comprometeu a colaborar com as investigações, a pagar uma multa de $R \$ 1$ bilhão e onde listou 8 propostas da companhia para um Brasil melhor. Esse manifesto foi escrito logo após a empresa fechar um acordo de leniência com a Justiça brasileira. (Bom Dia Brasil, 2016)

Porém, apesar dos esforços para manter a sua reputação após os escândalos citados, a Andrade Gutierrez sofreu impactos negativos em decorrência desses fatos. De acordo com os balanços publicados pela empreiteira, de um lucro líquido de $\mathrm{R} \$ 444,4$ milhões em 2013 , seus números passaram para um prejuízo de mais de $R$ \$ 150 milhões em 2016, ano em que seu presidente foi sentenciado.

Com isso, a carteira de obras da empreiteira caiu de $\mathrm{R} \$ 30$ bilhões em 2014 para $\mathrm{R} \$$ 18,3 bilhões em 2017, uma queda de 39\%, e em julho de 2018 a empresa teve seu rating de classificação de risco baixado pela Moody's para C, o pior nível da escala. Isso porque, a construtora tem enfrentado dificuldades em honrar com seus compromissos, como por 
exemplo uma dívida de $\mathrm{R} \$ 1$ 1,35 bilhão do começo de 2018 que não foi paga, e pelo fato de a $A G$ ter cerca de $\mathrm{R} \$ 508$ milhões bloqueados pelo Tribunal de Contas da União. (Estadão Conteúdo, 2018)

Assim sendo, levando em consideração os efeitos aparentes resultantes da Operação Lava Jato em uma das empresas sob investigação citados anteriormente, surge o questionamento: quanto os indicadores financeiros e a estrutura de capital de uma empresa investigada foram impactados pela operação em curso?

\subsection{Objetivo do estudo}

O presente estudo tem como principal objetivo apurar as consequências financeiras da Operação Lava Jato de uma empresa investigada.

\subsection{Objetivos intermediários do estudo}

Para que o objetivo final do estudo possa ser alcançado, é preciso primeiro passar por algumas etapas, sendo elas os objetivos intermediários:

a) Calcular os indicadores financeiros da empresa antes e depois da Operação Lava Jato;

b) Analisar os indicadores financeiros calculados;

c) Comparar os indicadores financeiros anteriores e posteriores à Operação Lava Jato e entender as mudanças sofridas pela companhia.

\subsection{Delimitação do estudo}

O período de tempo dos indicadores financeiros calculados e analisados neste estudo será restrito de 2012 a 2017. Dessa forma, serão analisados dois anos anteriores ao início da Lava Jato, para entender como encontrava-se a situação financeira do empreendimento sem a intervenção dessa externalidade, e quatro anos com a Lava Jato em curso, mostrando a transformação da empresa durante as investigações.

Além disso, embora o estudo tenha como objetivo entender os impactos nos indicadores financeiros de empresas investigadas, a análise será restrita à Andrade Gutierrez. Inicialmente, levantou-se a hipótese de estudar a Odebrecht, por esta ser uma das empresas com o nome mais conectado ao escândalo da Lava Jato. No entanto, como esta não possui mais suas ações na bolsa de valores, já que seu registro na BM\&F Bovespa foi cancelado em 2000 (BM\&F Bovespa), o acesso às duas informações financeiras seria demasiadamente 
restrito. Assim sendo, selecionou-se a Andrade Gutierrez para este estudo, pois trata-se de uma empresa que já ocupou o lugar de segunda maior construtora do país (Estadão Conteúdo, 2018), também envolvida na Operação Lava Jato e com ações listadas na bolsa de valores de São Paulo, o que permitirá fácil acesso aos seus demonstrativos financeiros. Com isso, será possível entender em profundidade as mudanças sofridas por uma das empresas presentes nas investigações em curso.

\subsection{Justificativa e relevância do estudo}

Embora o Brasil já tenha sofrido com escândalos de corrupção anteriormente, como o caso PC Farias, que acabou culminando no Impeachment do então presidente Fernando Collor de Mello (MUNDO EDUCAÇÃO) ou então o Mensalão, esquema de compra de votos de parlamentares descoberto em 2005 (INFO ESCOLA), nenhum teve a magnitude da Operação Lava Jato até então. Assim sendo, mostra-se válido entender os efeitos que a participação em tais eventos pode ter em uma empresa, mesmo que essa possua um nome sólido no mercado.

Ademais, além de expor as consequências de atitudes ilícitas no âmbito financeiro, os resultados obtidos podem ainda servir de exemplo para futuros empreendimentos que por ventura ainda cogitem seguir por esse caminho. Embora o escopo do estudo não abranja a percepção do consumidor em relação à empresa, os resultados financeiros acabam por mostrar indiretamente a percepção do mercado no tocante a determinado empreendimento. 


\section{Referencial Teórico}

Neste capítulo serão apresentados temas e conceitos importantes para o desenvolvimento das análises realizadas posteriormente. Esse item será dividido em três partes e irá discutir sobre a empresa estudada, a Andrade Gutierrez, sobre a Operação Lava Jato, motivação central do tema estudado e os indicadores necessários para entender de forma generalizada a situação financeira de um empreendimento.

\subsection{A Andrade Gutierrez}

A Andrade Gutierrez é uma multinacional brasileira que atua no ramo de engenharia e construção civil. A empresa está presente em mais de 20 países, empregando mais de 90 mil pessoas. Sua história começa no ano de 1948, quando os engenheiros e irmãos Gabriel e Roberto Andrade se juntaram ao amigo Flávio Gutierrez, em Belo Horizonte, para fundar uma pequena construtora, que dispunha apenas de um trator para realizar suas operações. Nesse mesmo ano, a empresa recém-criada foi contratada pela prefeitura de sua cidade natal para a canalização da Rua Rio Grande do Norte. (Andrade Gutierrez, 2018)

Com o passar dos anos a AG foi crescendo e se responsabilizando por obras cada vez maiores. A eleição de Juscelino Kubitschek para presidente da república em 1956 foi fundamental para esse crescimento, pois o plano de modernização do candidato, conhecido como Plano de Metas - no qual dizia-se que o país cresceria 50 anos em 5 - elevou o número de obras no Brasil.

Sendo assim, em 1957 a AG realiza sua primeira obra fora do Sudeste, a construção da rodovia que liga São Paulo a Curitiba, no Paraná, e continuando no ramo de construção de estradas pelos anos seguintes, como a rodovia Rio-Bahia (BR-116) e a rodovia Castelo Branco. No ano de 1971 a empreiteira inicia as obras das linhas norte e sul do metrô de São Paulo e, quatro depois, a construção da usina de Itaipu, o primeiro empreendimento binacional da companhia. Em 1977 a AG foi eleita a Empresa do Ano pela revista Exame e menos de 10 anos depois, em 1984, realizava sua primeira obra internacional, a construção da rodovia Epena-Impfondo-Dongou, no Congo.

A Andrade Gutierrez também foi responsável pela reurbanização do Vale do Anhangabaú, em São Paulo, pela construção de diversos aeroportos, como o de Confins (Belo Horizente - MG), o de Quito, no Equador e o do Nassau, nas Bahamas e pelo metrô de Lisboa, em Portugal. Recentemente, participou de grandes obras brasileiras, como a construção da Usina de Belo Monte (2010), a revitalização e construção de estádios para a Copa do Mundo, como o Maracanã e a Arena da Amazônia e a construção da Transcarioca e do Parque Olímpico para as Olimpíadas de 2016, sediada na cidade do Rio de Janeiro. 


\section{Figura 1 - Arena de Amazônia}

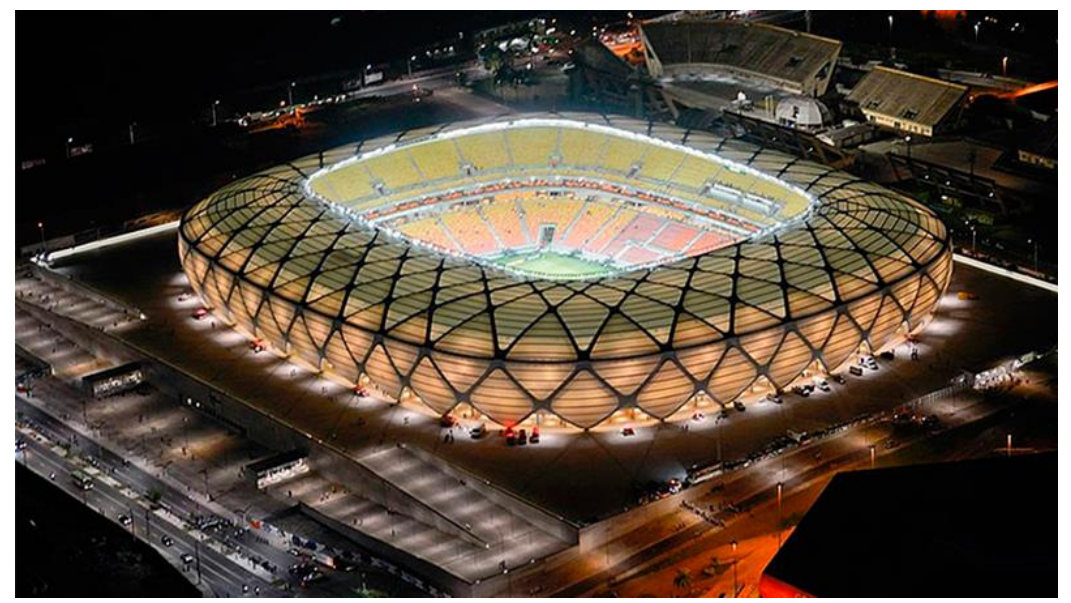

Fonte: Amazonas Atual

Com o crescimento de sua atuação, a Andrade Gutierrez dividiu-se em várias empresas, sendo a sua holding, a Andrade Gutierrez Participações S.A., responsável pelas estratégias e pelo monitoramento de resultado de suas controladas, de acordo com o seu Relatório de Administração de 2017. Segundo a mesma fonte citada anteriormente, as controladas atuam em três segmentos distintos:

O primeiro deles é o segmento de Concessões, representado pela empresa AG Concessões S.A. Esta é uma holding, da qual a Andrade Gutierrez tem 100\% de participação, que gere e desenvolve empreendimentos relacionados à concessões e participações em obras públicas de infraestrutura. A AG Concessões detém capital social de empreendimentos atuantes na área de prestação de serviço público nas áreas de rodovias, transporte urbano e metro-ferroviário e aeroportos, como por exemplo a CCR, da qual possui uma participação de $14,52 \%$. É desse segmento que vem a maior parte do resultado da Andrade Gutierrez Participações.

Além do segmento Concessões, há o segmento Madeira Energia, representado pela controlada SAAG que controla $12,40 \%$ da Madeira Energia S.A, chamada de MESA. Esta última detém $100 \%$ do controle da Santo Antônio Energia S.A, concessionária responsável pela construção e exploração da Usina Hidrelétrica de Santo Antônio e seus transmissores, no Rio Madeira, em Porto Velho, Rondônia.

O terceiro segmento no qual a $A G$ atua foi denominado de "Outros" pela companhia. Este é representado pela empresa SPE Holding Beira Rio S.A., que tem como atividade a construção, renovação e operação - até 2032 - do Complexo Beira-Rio, estádio que sediou a Copa do Mundo de 2014 em Porto Alegre, Rio Grande do Sul. Em 2013 o Conselho de Administração da SPE definiu a constituição da HBR Gestão Administração Imobiliária S.A., 
que será responsável pela operação de catering, exploração das área de loja e do edifício garagem do Complexo Beira-Rio.

Figura 2- Estrutura de participações da Andrade Gutierrez Participações

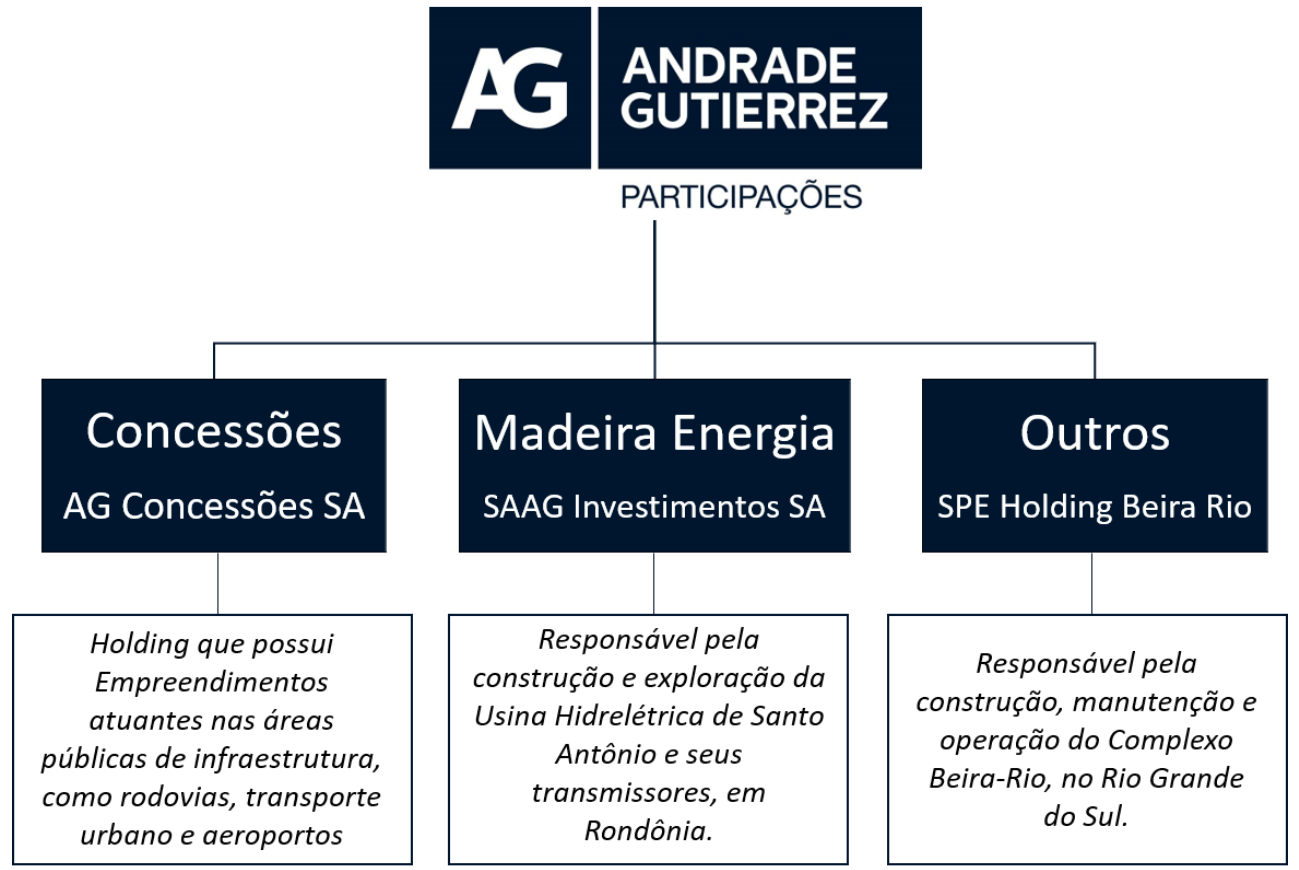

Fonte: Elaborado pela autora a partir de dados do Relatório de Administração da AG

\subsection{A Operação Lava Jato}

As investigações que deram origem à operação Lava Jato tiveram início em 2009, quando a polícia federal começou a investigar um grupo de doleiros, entre eles Alberto Youssef, devido a uma suspeita de lavagem de dinheiro. Estes atuavam em todo o território brasileiro por meio de empresas de fachada, contas em paraísos fiscais e contratos de importação fictícios para tornar lícito montantes de dinheiro desviados dos cofres públicos.

Após a prisão de dois doleiros investigados e por meio de suas delações premiadas, descobriu-se um vasto esquema de corrupção. Este envolvia inúmeros políticos, a Petrobrás, uma das grandes companhias de economia mista - na qual o Governo é acionista majoritário - e diversas empreiteiras, tais quais a Odebrecht, Andrade Gutierrez, OAS, Queiroz Galvão, entre outras. No esquema formado entre as partes, era cobrada propina das empreiteiras para que estas pudessem obter facilidades nas licitações das quais faziam parte e, assim, serem selecionadas para a realização de obras públicas, como a reforma do Maracanã. (BRASIL ESCOLA)

Além disso, os contratos firmados eram superfaturados para facilitar o desvio de dinheiro público e repasse para diretores da Petrobrás e políticos de diversos partidos. De acordo com 
uma matéria do G1, estima-se que o prejuízo causado na Petrobras por meio de desvio de dinheiro poderia chegar à $\mathrm{R} \$ 42$ bilhões. Este valor foi calculado de acordo com os repasses efetuados para as 27 empresas que compunham o cartel da petrolífera e com base no percentual de $3 \%$, divulgado em uma das delações obtidas durante as investigações. (DIONISIO, 2015).

A Lava Jato completou 4 anos em março de 2018 e ainda continua em curso, contendo mais de 49 fases. A Operação já foi responsável por 188 condenações, sendo a mais importante delas a condenação do ex-presidente Luiz Inácio Lula da Silva, sentenciado a 9 anos de prisão pelos crimes de corrupção passiva e lavagem de dinheiro. (PAVANELI, 2018). Segue um breve esquema explicativo das partes envolvidas no esquema e de seus respectivos papéis. 
Figura 3 - Como Funcionada a Operação Lava Jato

\section{COMO FUNCIONAVA 0 ESQUEMA}

Segundo os procuradores da Operação Lava Jato

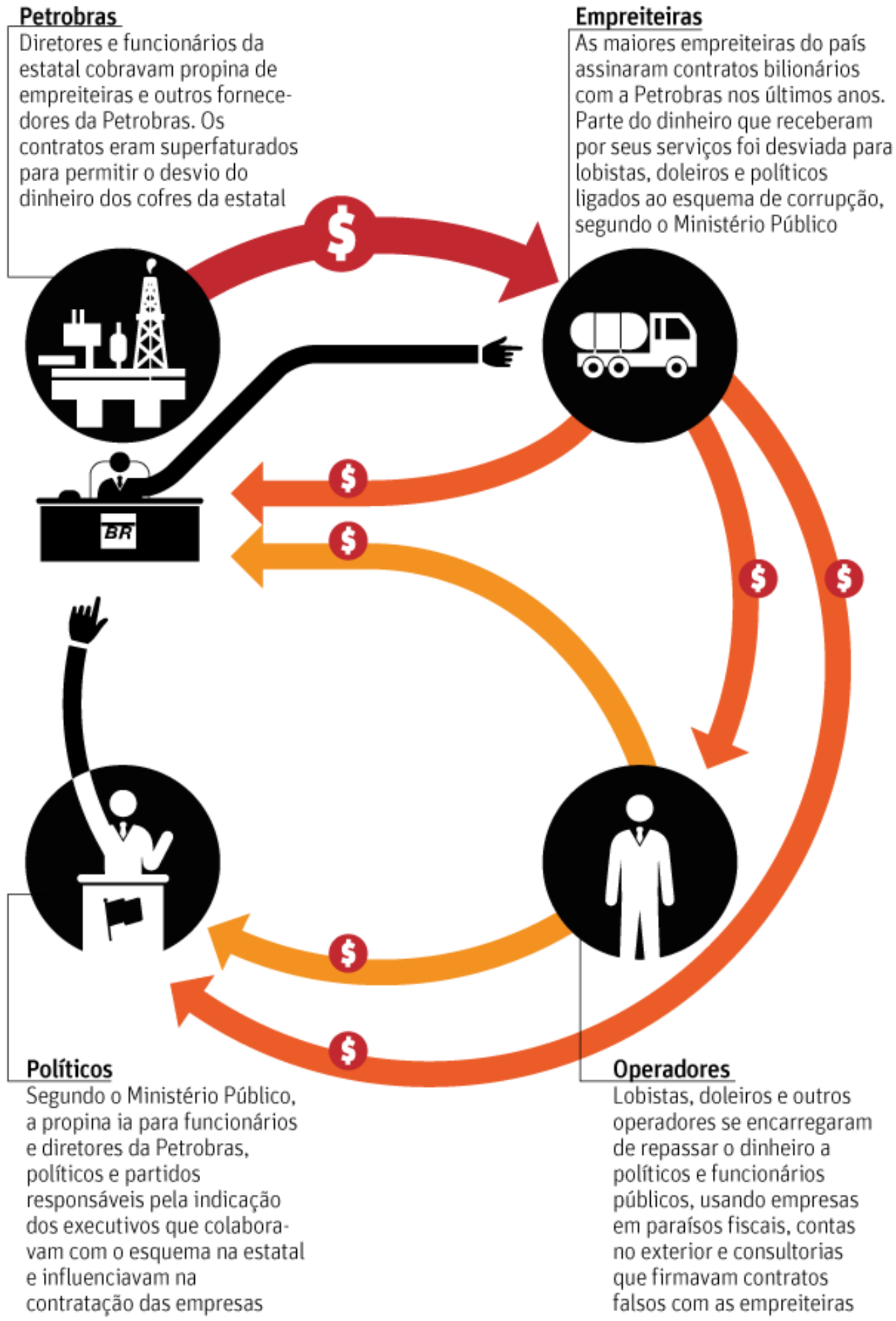

Fonte: Folha de São Paulo 


\subsection{Análise de Indicadores}

De acordo com Marion (2009) uma das formas de apurar a situação de uma empresa, em diferentes aspectos, é por meio de seus indicadores contábeis. Dessa forma, segundo Ross (2013) os indicadores financeiros permitem a comparação e a investigação de diferentes informações com relação à empresa. Assim sendo, para esse estudo serão utilizados índices de Liquidez, Estrutura de Capital, Rentabilidade e Lucratividade. Será apurado ainda o Fator de Insolvência e as análises vertical e horizontal, conforme explicado nos subitens que se seguem.

\subsubsection{Indicadores de Liquidez}

Segundo Silva (2017) os indicadores de liquidez têm como objetivo sinalizar se a empresa analisada tem capacidade de arcar com as suas dívidas, levando em consideração seus Ativos em comparação com seu Passivo. Assim, a liquidez resulta da capacidade de a empresa ser lucrativa, como consequência de sua administração e do contexto ao seu redor. Neste estudo serão abordados os seguintes índices de liquidez: geral, corrente e imediata.

\subsubsection{Liquidez Geral}

A liquidez geral indica a situação financeira da empresa de forma global, isto é, a capacidade da companhia de pagar suas dívidas de curto e longo prazo (MARION, 2012), e é calculada da seguinte forma:

$$
\text { Liquidez Geral: } \frac{\text { Ativo Circulante }+ \text { Realizável a Longo Prazo }}{\text { Passivo Circulante + Passivo Não Circulante }}
$$

Esse indicador mostra de cada $R \$ 1$ que a empresa possui de dívida, o quanto existe de direitos e haveres no Ativo, sendo então um indicador de segurança financeira. (ASSAF NETO, 2012) Dessa forma, quanto maior, melhor. (SILVA, 2017)

\subsubsection{Liquidez Corrente}

A liquidez corrente pode ser calculada pela razão do ativo circulante com o passivo circulante, conforme fórmula a seguir: 


$$
\text { Liquidez Corrente }=\frac{\text { Ativo Circulante }}{\text { Passivo Circulante }}
$$

Este indicador mede a capacidade da empresa em honrar suas obrigações de curto prazo somente com o que dispõe (MARION, 2012). Para Ross (2013) a liquidez corrente aponta a liquidez de curto prazo e, sob o ponto de vista da empresa, quando o índice está alto indica sobra de recursos, mas por outro lado, pode sugerir um uso ineficiente do caixa e de outros ativos de curto prazo.

\subsubsection{Liquidez Imediata}

A liquidez imediata indica o percentual de dívidas de curto prazo da organização que esta consegue liquidar imediatamente, ou seja, apenas com o que dispõe na sua linha caixa a bancos do ativo. No entanto, esse valor é comumente baixo, devido ao pouco interesse das empresas de manterem uma grande quantia em caixa, já que esse é um ativo de baixa rentabilidade. (ASSAF NETO, 2012)

$$
\text { Liquidez Imediata: } \frac{\text { Disponível (Caixa e Bancos) }}{\text { Passivo Circulante }}
$$

\subsubsection{Indicadores de Rentabilidade e Lucratividade}

De acordo com Marion (2012, p. 140) a rentabilidade da empresa pode ser definida como "quanto a empresa obteve de lucro (retorno) por cada $R \$ 1,00$ investido" e pode ser analisada sob a perspectiva da empresa e do empresário (ROSS, 2013).

\subsubsection{Return On Equity (ROE)}

O Return On Equity, mais comumente conhecido como ROE, é formado pela divisão do lucro líquido pelo patrimônio líquido - conforme ilustrado pela fórmula a seguir - e indica qual o retorno para o acionista para cada $R \$ 1,00$ investido na empresa e, assim sendo, quanto maior, mais atrativo. (ROSS, 2013)

$$
\text { ROE: } \frac{\text { Lucro Líquido }}{\text { Patrimônio Líquido }} \times 100
$$




\subsubsection{Retorn On Asset (ROA)}

Já o Return On Asset, também chamado de ROA, mede o lucro por real em ativos, (ROSS, 2013) isto é, para cada $R \$ 1,00$ investido no ativo quanto há de retorno, em média e, assim como o ROE, quanto maior, melhor.

$$
\text { ROA: } \frac{\text { Lucro Líquido }}{\text { Total de Ativos }} \times 100
$$

\subsubsection{Margem Líquida}

Um dos indicadores mais importantes a ser apurado é a margem líquida, sendo um dos índices mais conhecido e utilizado. Isso porque, ele é usado para medir a eficiência operacional de uma empresa em gerir seus recursos, administrar suas operações e utilizar seus ativos e, consequentemente, quanto maior, melhor. Para o cálculo desse indicador é necessário dividir o lucro líquido pelo total de vendas, (ROSS, 2013) conforme ilustrado na fórmula a seguir:

$$
\text { Margem Líquida: } \frac{\text { Lucro Líquido }}{\text { Vendas (Receita Líquida) }} \times 100
$$

\subsubsection{Indicadores de Estrutura de Capital}

A estrutura de capital de um empreendimento pode ser descrita, de acordo com Silva (2004 apud ORO, BEUREN e HEIN, 2009) como as fontes de financiamento de uma empresa, podendo ela ser própria ou proveniente de terceiros. Brigham e Houston (1999) afirmam que a estrutura de capital ótima não é uma ciência exata, até porque muitos são os fatores que a influenciam. Para Assaf Neto (2012) a composição ótima da estrutura de capital ocorre quando há a maximização da riqueza do empreendimento enquanto ocorre uma diminuição dos custos totais de financiamento. Neste tópico serão apresentados os seguintes indicadores: participação de capitais de terceiros, composição do endividamento, grau de endividamento e grau de alavancagem financeira. 


\subsubsection{Participação de Capitais de Terceiros}

Segundo Assaf Neto (2012), o índice de capitais de terceiros mostra a porcentagem de capital de terceiros em relação ao patrimônio líquido, ou seja, quanto do capital próprio é proveniente de terceiros. Também é chamado de índice de endividamento ou índice de alavancagem, e é calculado da seguinte forma:

$$
\text { Participação de Capitais de Terceiros: } \frac{\text { Passivo Exigível Total }}{\text { Total do Ativo }} \text { X } 100
$$

De acordo com o autor, a interpretação desse indicador não é simples e envolve uma análise do contexto e das consequências de um endividamento, mas, isoladamente, a partir de um certo nível a participação de terceiros pode ser ruim, pois significa um risco maior para os credores e pode aumentar a chance de falência. No entanto, um elevado índice de alavancagem pode significar um aumento no preço das ações e pode valer a pena se o custo da dívida for inferior ao rendimento gerado pela aplicação desse empréstimo. (ASSAF NETO, 2012)

\subsubsection{Composição do Endividamento}

A composição do Endividamento, ainda segundo Assaf Neto, mostra a composição do endividamento em relação aos prazos de vencimento, ou seja, quanto do total da dívida deverá ser quitado no curto prazo. (ASSAF NETO, 2012)

$$
\text { Composição do Endividamento: } \frac{\text { Passivo Circulante }}{\text { Passivo Circulante + Passivo Não Circulante }} \times 100
$$

Esse indicador, quanto maior, pior, pois quanto maior o valor da dívida a ser pago no curto prazo, maior a pressão da empresa em gerar recursos suficientes para arcar com tais dívidas. (ASSAF NETO, 2012)

\subsubsection{Grau de endividamento}

Para Assaf Neto, o endividamento sinaliza o "quanto a empresa tomou emprestado para cada \$ 1 de capital próprio aplicado" (ASSAF NETO, 2012, p.149) e pode ser calculado conforme a equação descrita a seguir: 


$$
\text { Grau de Endividamento: } \frac{\text { Passivo Exigível Total }}{\text { Patrimônio Líquido }}
$$

Assim como a Participação de Capitais de Terceiros, sua análise é complexa e envolve um entendimento da relação entre o custo do empréstimo e o retorno gerado.

\subsubsection{Grau de alavancagem financeira}

Segundo Silva, (2017) o Grau de Alavancagem Financeiro (GAF) pode ser calculado pela divisão do ROE pelo ROA (ROE / ROA). Utilizando as fórmulas desses dois indicadores (mostradas nos itens 2.3.2.1 e 2.3.2.2 respectivamente) e aplicando as regras de divisão de frações, é possível chegar na seguinte equação para o GAF:

$$
\text { GAF: } \frac{\text { Ativo }}{\text { Patrimônio Líquido }}
$$

Para Assaf Neto (2012, p. 123), o GAF pode ser definido como "a capacidade que os recursos de terceiros apresentam de elevar os resultados líquidos dos proprietários", e seu nome vem de uma associação com o uso de alavancas na física, onde elas são usadas para mover objetos com o uso de menos força. (SILVA, 2017)

\subsubsection{Fator de Insolvência}

Um outro aspecto a ser analisado e o Fator de Insolvência da empresa. Esse indicador foi desenvolvido pelo professor Stephen Charles Kanitz e mostra a propensão da empresa a falir. Para isso, é necessário calcular o fator de insolvência e então analisa-lo de acordo com uma escala criada pelo autor, chamada de Termômetro de Insolvência (KASSAI, 1998). Tanto a fórmula para o cálculo do fator como o termômetro de insolvência podem ser vistos a seguir.

Fator de insolvência $=0,05 X_{1}+1,65 X_{2}+3,55 X_{3}-1,06 X_{4}-0,33 X_{5}$

Onde:

$X_{1}=R O E$ 


$$
\begin{aligned}
& X_{2}=\text { Liquidez } \text { geral } \\
& X_{3}=\text { Liquidez seca }^{1} \\
& X_{4}=\text { Liquide } \text { corrente } \\
& X_{5}=\text { Grau de endividamento }
\end{aligned}
$$

Figura 4- Termômetro de Insolvência

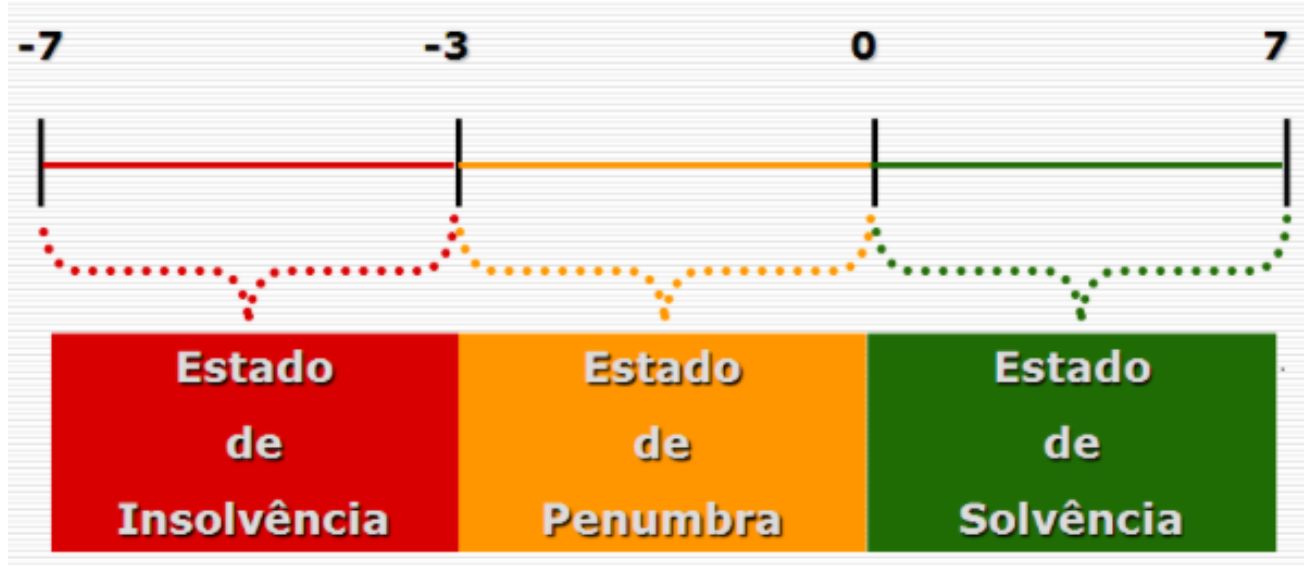

Fonte: Partitura Financeira

Dessa forma, quando a empresa se encontra com o fator de insolvência entre 0 e 7 , sua situação é solvente, ou seja, com poucas chances de falência. Quando o indicador aponta valores entre -7 e -3, a companhia encontra-se em estado de insolvência, o que aponta uma grande tendência à falência. O estado de penumbra, quando o fator está entre - 3 e 0 , mostra uma incerteza no resultado pois nesse caso o fator de insolvência não é suficiente para mostrar um diagnóstico, mas aponta que deve-se ficar alerta. (KASSAI, 1998)

${ }^{1}$ Liquidez seca é um indicador que avalia o percentual das dívidas de curto prazo a serem pagos apenas com as ativos de maior liquidez (ASSAF NETO, 2012), ou seja, revela quanto a empresa depende de seus estoques para saldar suas dívidas. É calculada da seguinte forma: (Ativo Circulante - Estoques) / Passivo Circulate. 


\section{Metodologia}

\subsection{Levantamento de Informações}

Para calcular os indicadores utilizados no presente estudo, citados anteriormente, foi necessário o acesso às informações financeiras da Andrade Gutierrez. Estas foram obtidas no site da companhia, por meio de seu portal de Relacionamento com Investidores. Assim sendo, foram utilizados os Balanços Patrimoniais (BP) e Demonstrações do Resultados do Exercício (DRE) publicados pela própria construtora para seus investidores, o que atesta um caráter de confiabilidade aos dados. Mostra-se válido ressaltar que os dados dos anos de 2012, 2013 e 2014 foram obtidos nas demonstrações financeiras de 2014 e os dados dos três anos subsequentes $(2015,2016$ e 2017) foram retirados das publicações de 2017. Sendo assim, foram usadas as informações mais recentes de cada ano divulgadas pela AG. Todos os BPs e DREs podem ser consultados na seção "Anexos" deste estudo.

Além das demonstrações financeiras, foram analisados também - quando necessário as notas explicativas publicadas em conjuntos com as informações financeiras e os Relatórios da Administração, publicados também no mesmo documento em que os demonstrativos financeiros. Outra fonte de consulta foram livros acerca de estudo de balanços e indicadores financeiros, todos listados no Referencial Teórico.

Após a coleta dos números da Andrade Gutierrez, foi preciso calcular seus indicadores, para poder iniciar a análise e comparação de sua situação financeira nos últimos seis anos. Esses cálculos foram efetuados pela autora, por meio da ferramenta Excel.

\subsection{Limitações do Estudo}

Inicialmente, o intuito do estudo era de calcular os indicadores financeiros de oito anos, de 2010 a 2017, pois como a operação Lava Jato teve início em 2014, seriam analisados os indicadores de quatro anos anteriores à investigação $(2010,2011,2012$ e 2013) e quatro anos com a investigação em curso (2014, 2015, 2016 e 2017).

Porém, no início das pesquisas nas demonstrações financeiras da Andrade Gutierrez constatou-se que de 2012 a 2013 houve uma mudança na legislação contábil, conforme previsto no CPC 23 - Políticas Contábeis, Mudança de Estimativa e Retificação de Erro. Com isso, a AG publicou, no BP de 2013 os resultados ajustados para 2012, com o intuito de permitir a comparabilidade entre os dois exercícios. No entanto, esse mesmo ajuste não foi aplicado aos anos de 2010 e 2011, fazendo com que a comparação entre esses anos e os demais não fosse compatível. Assim sendo, decidiu-se por excluir os períodos de 2010 e 2011 e trabalhar apenas com os seis anos subsequentes. 
Outra limitação do estudo é em relação ao número de empresas analisadas. Embora o objetivo do trabalho fosse entender os impactos nos indicadores financeiros de empresas investigadas, devido à limitação de tempo e mão de obra disponíveis, optou-se por restringir o estudo a uma companhia, a fim de não comprometer a qualidade do trabalho realizado. Além disso, acredita-se que a Andrade Gutierrez, por ter ocupado o lugar de segunda maior construtora do Brasil, irá representar de forma fundamentada o cenário vivenciado pelas demais empresas envolvidas na Lava Jato. 


\section{Apresentação e Análise dos Resultados}

\subsection{Análise Vertical}

Tabela 1 - Análise Vertical do Ativo

\begin{tabular}{|c|c|c|c|c|c|c|c|c|c|c|c|c|}
\hline \multirow{2}{*}{ (R\$ mil) } & \multicolumn{2}{|c|}{2017} & \multicolumn{2}{|c|}{2016} & \multicolumn{2}{|c|}{2015} & \multicolumn{2}{|c|}{2014} & \multicolumn{2}{|c|}{2013} & \multicolumn{2}{|c|}{2012} \\
\hline & $\mathrm{R} \$$ & $\%$ Vertical & $\mathrm{R} S{ }^{2}$ & $\%$ Vertical & 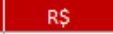 & $\%$ Vertical & $\mathrm{R} \$$ & $\%$ Vertical & $\mathrm{R} S$ & $\%$ Vertical & $\mathrm{RS}$ & $\%$ Vertical \\
\hline Ativo total & 2.557.132 & & 3.378 .698 & & 4.873.221 & & 5.473.319 & & 5.240 .984 & & 5.319 .532 & \\
\hline Ativo Circulante & 481.580 & $19 \%$ & 401.347 & $12 \%$ & 1.281 .982 & $26 \%$ & 1.200 .089 & $22 \%$ & 813.728 & $16 \%$ & 1.351 .555 & $25 \%$ \\
\hline Caixa e equivalentes de caixa & 344.041 & $13 \%$ & 303.079 & $9 \%$ & 632.185 & $13 \%$ & 935.256 & $17 \%$ & 605.408 & $12 \%$ & 931.161 & $18 \%$ \\
\hline Aplicações Financeiras & 30.389 & $1 \%$ & 28.613 & $1 \%$ & 485.561 & $10 \%$ & 0 & $0 \%$ & 0 & $0 \%$ & 0 & $0 \%$ \\
\hline contas a receber & 8.889 & $0 \%$ & 8.612 & $0 \%$ & 0 & $0 \%$ & 3 & $0 \%$ & 766 & $0 \%$ & 895 & $0 \%$ \\
\hline Tributos a recuperar & 12.994 & $1 \%$ & 22.769 & $1 \%$ & 20.316 & $0 \%$ & 32.084 & $1 \%$ & 24.224 & $0 \%$ & 48.258 & $1 \%$ \\
\hline Outros ativos circulantes & 85.267 & $3 \%$ & 38.274 & $1 \%$ & 143.920 & $3 \%$ & 232.746 & $4 \%$ & 183.330 & $3 \%$ & 371.208 & $7 \%$ \\
\hline Ativo Não Circulante & 2.075 .552 & $81 \%$ & 2.977 .351 & $88 \%$ & 3.591 .239 & $74 \%$ & 4.273 .230 & $78 \%$ & 4.427.256 & $84 \%$ & 3.967 .977 & $75 \%$ \\
\hline Ativo Realizável a longo prazo & 26.232 & $1 \%$ & 26.268 & $1 \%$ & 39.730 & $1 \%$ & 0 & $0 \%$ & 2.311 & $0 \%$ & 1.450 & $0 \%$ \\
\hline Investimentos & 2.017.374 & $79 \%$ & 2.918 .178 & $86 \%$ & 3.508 .785 & $72 \%$ & 4.229 .344 & $77 \%$ & 4.413 .975 & $84 \%$ & 3.910 .503 & $74 \%$ \\
\hline Imobilizado & 98 & $0 \%$ & 145 & $0 \%$ & 25.103 & $1 \%$ & 25.125 & $0 \%$ & 266 & $0 \%$ & 38.832 & $1 \%$ \\
\hline Intangivel & 31.848 & $1 \%$ & 32.760 & $1 \%$ & 17.621 & $0 \%$ & 18.761 & $0 \%$ & 10.704 & $0 \%$ & 17.192 & $0 \%$ \\
\hline
\end{tabular}

Fonte: Elaborado pela autora a partir de dados do Relatório de Administração da AG

Tabela 2 - Análise Vertical do Passivo e Patrimônio Líquido

\begin{tabular}{|c|c|c|c|c|c|c|c|c|c|c|c|c|}
\hline \multirow{2}{*}{ (R\$ mil) } & \multicolumn{2}{|c|}{2017} & \multicolumn{2}{|c|}{2016} & \multicolumn{2}{|c|}{2015} & \multicolumn{2}{|c|}{2014} & \multicolumn{2}{|c|}{2013} & \multicolumn{2}{|c|}{2012} \\
\hline & $\mathrm{RS}$ & $\%$ Vertical & $\mathrm{RS}$ & $\%$ Vertica & $\mathrm{RS}$ & $\%$ Vertical & $\mathrm{RS}$ & $\%$ Vertical & $\mathrm{RS}$ & $\%$ Vertical & $\mathrm{RS}$ & $\%$ Vertical \\
\hline Passivo Total & 2.557 .132 & & 3.378 .698 & & 4.873.221 & & 5.473 .319 & & 5.240 .984 & & 5.319 .532 & \\
\hline Passivo Circulante & 274.423 & $11 \%$ & 732.559 & $22 \%$ & 727.761 & $15 \%$ & 525.744 & $10 \%$ & 325.167 & $6 \%$ & 598.904 & $11 \%$ \\
\hline Obrigações sociais e trabalhistas & 4.711 & $0 \%$ & 7.643 & $0 \%$ & 11.638 & $0 \%$ & 13.932 & $0 \%$ & 2.106 & $0 \%$ & 2.521 & $0 \%$ \\
\hline Fornecedores & 7.735 & $0 \%$ & 6.129 & $0 \%$ & 4.785 & $0 \%$ & 46 & $0 \%$ & 85 & $0 \%$ & 339 & $0 \%$ \\
\hline Obrigações Fiscais & 6.211 & $0 \%$ & 158 & $0 \%$ & 158 & $0 \%$ & 156 & $0 \%$ & 8.186 & $0 \%$ & 36.375 & $1 \%$ \\
\hline Empréstimos e financiamentos & 145.701 & $6 \%$ & 684.953 & $20 \%$ & 687.260 & $14 \%$ & 425.909 & $8 \%$ & 183.561 & $4 \%$ & 391.102 & $7 \%$ \\
\hline Outras obrigções & 110.065 & $4 \%$ & 33.676 & $1 \%$ & 23.920 & $0 \%$ & 85.701 & $2 \%$ & 131.229 & $3 \%$ & 168.567 & $3 \%$ \\
\hline Passivo não Circulante & 2.081 .421 & $81 \%$ & 590.493 & $17 \%$ & 1.332 .214 & $27 \%$ & 2.021 .391 & $37 \%$ & 2.617 .154 & $50 \%$ & 2.450 .952 & $46 \%$ \\
\hline Empréstimos e financiamentos & 2.078 .668 & $81 \%$ & 589.509 & $17 \%$ & 1.329 .461 & $27 \%$ & 2.015 .320 & $37 \%$ & 2.580 .625 & $49 \%$ & 2.409 .916 & $45 \%$ \\
\hline Outras Obrigaçỗes & 2.753 & $0 \%$ & 984 & $0 \%$ & 2.753 & $0 \%$ & 6.071 & $0 \%$ & 36.529 & $1 \%$ & 41.036 & $1 \%$ \\
\hline Patrimônio Líquido Consolidado & 201.288 & $8 \%$ & 2.055 .646 & $61 \%$ & 2.813.246 & $58 \%$ & 2.926 .184 & $53 \%$ & 2.298 .663 & $44 \%$ & 2.269 .676 & $43 \%$ \\
\hline Capital Social Realizado & 2.377 & $0 \%$ & 1.292 .377 & $38 \%$ & 1.292 .377 & $27 \%$ & 1.292 .377 & $24 \%$ & 1.114 .377 & $21 \%$ & 1.078 .236 & $20 \%$ \\
\hline Reservas de Lucro & 137.453 & $5 \%$ & 421.714 & $12 \%$ & 1.034 .007 & $21 \%$ & 1.090 .154 & $20 \%$ & 1.437 .911 & $27 \%$ & 1.173 .738 & $22 \%$ \\
\hline Lucros/Prejuízos Acumulados & -133.442 & $-5 \%$ & 0 & $0 \%$ & 0 & $0 \%$ & 0 & $0 \%$ & 0 & $0 \%$ & 0 & $0 \%$ \\
\hline Ajustes de Avaliação Patrimonial & -193.802 & $-8 \%$ & -227.235 & $-7 \%$ & -112.350 & $-2 \%$ & -138.837 & $-3 \%$ & -274.921 & $-5 \%$ & -182.142 & $-3 \%$ \\
\hline Participação dos acionistas não controladores & 388.702 & $15 \%$ & 568.790 & $17 \%$ & 599.212 & $12 \%$ & 682.490 & $12 \%$ & 21.296 & $0 \%$ & 199.844 & $4 \%$ \\
\hline
\end{tabular}

Fonte: Elaborado pela autora a partir de dados do Relatório de Administração da AG

O primeiro passo para analisar os indicadores financeiros de um empreendimento é entender as rubricas mais significativas de seus demonstrativos, o que pode ser feito por meio da análise vertical, que tem como objetivo mostrar a participação de cada rubrica em relação à um item específico, normalmente em relação ao Ativo Total (para as rubricas do ativo) e o Passivo Total (para as contas do passivo). (SILVA, 2017)

Assim sendo, a partir do cálculo desse percentual, o primeiro ponto a ser destacado nos Ativos da Andrade Gutierrez é a diferença entre o Ativo Circulante e o Ativo Não Circulante, sendo o primeiro de aproximadamente $20 \%$. Isso mostra que a maioria, cerca de $80 \%$ dos Ativos da AG, são de longo prazo. Dentro dessas linhas, nota-se que a maior participação 
provém da rubrica "Investimentos", o que pode ser explicado pelo fato de a Andrade Gutierrez Participações ser uma holding, ou seja, uma companhia destinada a ter participação acionária em outras empresas e essa é uma das linhas onde essas participações são reconhecidas no Balanço Patrimonial.

Em relação ao Passivo, até o ano de 2016 havia um equilíbrio entre o Passivo Exigível e o Patrimônio Líquido, mas esse cenário mudou no ano de 2017. Esse ponto será explorado mais adiante na avaliação horizontal das demonstrações financeiras. Analisando apenas o capital de terceiros, é possível observar que o maior valor, principalmente de 2012 a 2015, é o de empréstimos e financiamentos de longo prazo, o que indica que a companhia pode usar a alavancagem financeira como estratégia, tópico que será discutido mais adiante na análise dos indicadores de endividamento.

\subsection{Análise Horizontal}

Tabela 3 - Análise Horizontal do Ativo

\begin{tabular}{|c|c|c|c|c|c|c|c|c|c|c|c|}
\hline \multirow{2}{*}{ (R\$ mil) } & \multicolumn{2}{|c|}{2017} & \multicolumn{2}{|c|}{2016} & \multicolumn{2}{|c|}{2015} & \multicolumn{2}{|c|}{2014} & \multicolumn{2}{|c|}{2013} & \multirow{2}{*}{$\begin{array}{c}2012 \\
\mathrm{RS}\end{array}$} \\
\hline & $\mathrm{RSS}$ & $\%$ Horizontal & $\mathrm{RS}$ & $\%$ Horizonta & $\mathrm{RS}$ & $\%$ Horizonta & $\mathrm{RS}$ & \% Horizonta & $\mathrm{RSS}$ & $\%$ Horizonta & \\
\hline Ativo total & 2.557 .132 & $-24 \%$ & 3.378.698 & $-31 \%$ & 4.873.221 & $-11 \%$ & 5.473.319 & $4 \%$ & 5.240 .984 & $-1 \%$ & 5.319 .532 \\
\hline Ativo Circulante & 481.580 & $20 \%$ & 401.347 & $-69 \%$ & 1.281 .982 & $7 \%$ & 1.200 .089 & $47 \%$ & 813.728 & $-40 \%$ & 1.351 .555 \\
\hline Caixa e equivalentes de caixa & 344.041 & $14 \%$ & 303.079 & $-52 \%$ & 632.185 & $-32 \%$ & 935.256 & $54 \%$ & 605.408 & $-35 \%$ & 931.161 \\
\hline Aplicações Financeiras & 30.389 & $6 \%$ & 28.613 & $-94 \%$ & 485.561 & - & 0 & - & 0 & - & 0 \\
\hline contas a receber & 8.889 & $3 \%$ & 8.612 & - & 0 & $-100 \%$ & 3 & $-100 \%$ & 766 & $-14 \%$ & 895 \\
\hline Tributos a recuperar & 12.994 & $-43 \%$ & 22.769 & $12 \%$ & 20.316 & $-37 \%$ & 32.084 & $32 \%$ & 24.224 & $-50 \%$ & 48.258 \\
\hline Outros ativos circulantes & 85.267 & $123 \%$ & 38.274 & $-73 \%$ & 143.920 & $-38 \%$ & 232.746 & $27 \%$ & 183.330 & $-51 \%$ & 371.208 \\
\hline Ativo Não Circulante & 2.075 .552 & $-30 \%$ & 2.977 .351 & $-17 \%$ & 3.591 .239 & $-16 \%$ & 4.273 .230 & $-3 \%$ & 4.427 .256 & $12 \%$ & 3.967.977 \\
\hline Ativo Realizável a longo prazo & 26.232 & $0 \%$ & 26.268 & $-34 \%$ & 39.730 & - & 0 & $-100 \%$ & 2.311 & $59 \%$ & 1.450 \\
\hline Investimentos & 2.017.374 & $-31 \%$ & 2.918 .178 & $-17 \%$ & 3.508.785 & $-17 \%$ & 4.229 .344 & $-4 \%$ & 4.413 .975 & $13 \%$ & 3.910 .503 \\
\hline Imobilizado & 98 & $-32 \%$ & 145 & $-99 \%$ & 25.103 & $0 \%$ & 25.125 & $9345 \%$ & 266 & $-99 \%$ & 38.832 \\
\hline Intangível & 31.848 & $-3 \%$ & 32.760 & $86 \%$ & 17.621 & $-6 \%$ & 18.761 & $75 \%$ & 10.704 & $-38 \%$ & 17.192 \\
\hline
\end{tabular}

Fonte: Elaborado pela autora a partir de dados do Relatório de Administração da AG 
Tabela 4 - Análise Horizontal do Passivo e Patrimônio Líquido

\begin{tabular}{|c|c|c|c|c|c|c|c|c|c|c|c|}
\hline \multirow{2}{*}{ (R\$ mil) } & \multicolumn{2}{|c|}{2017} & \multicolumn{2}{|c|}{2016} & \multicolumn{2}{|c|}{2015} & \multicolumn{2}{|c|}{2014} & \multicolumn{2}{|c|}{2013} & \multirow{2}{*}{$\begin{array}{c}2012 \\
\text { RS }\end{array}$} \\
\hline & $\mathrm{RS}$ & \% Horizontal & RS & $\%$ Horizonta & RS & \% Horizonta & $\mathrm{RS}$ & \%o Horizonta & $\mathrm{RS}$ & $\%$ Horizonta & \\
\hline Passivo Total & 2.557 .132 & $-24 \%$ & 3.378.698 & $-31 \%$ & 4.873.221 & $-11 \%$ & 5.473.319 & $4 \%$ & 5.240 .984 & $-1 \%$ & 5.319.532 \\
\hline Passivo Circulante & 274.423 & $-63 \%$ & 732.559 & $1 \%$ & 727.761 & $38 \%$ & 525.744 & $62 \%$ & 325.167 & $-46 \%$ & 598.904 \\
\hline Obrigações sociais e trabalhistas & 4.711 & $-38 \%$ & 7.643 & $-34 \%$ & 11.638 & $-16 \%$ & 13.932 & $562 \%$ & 2.106 & $-16 \%$ & 2.521 \\
\hline Fornecedores & 7.735 & $26 \%$ & 6.129 & $28 \%$ & 4.785 & $10302 \%$ & 46 & $-46 \%$ & 85 & $-75 \%$ & 339 \\
\hline Obrigações Fiscais & 6.211 & $3831 \%$ & 158 & $0 \%$ & 158 & $3 \quad 1 \%$ & 156 & $-98 \%$ & 8.186 & $-77 \%$ & 36.375 \\
\hline Empréstimos e financiamentos & 145.701 & $-79 \%$ & 684.953 & $0 \%$ & 687.260 & $61 \%$ & 425.909 & $132 \%$ & 183.561 & $-53 \%$ & 391.102 \\
\hline Outras obrigções & 110.065 & $227 \%$ & 33.676 & $41 \%$ & 23.920 & $-72 \%$ & 85.701 & $-35 \%$ & 131.229 & $-22 \%$ & 168.567 \\
\hline Passivo não Circulante & 2.081 .421 & $252 \%$ & 590.493 & $-56 \%$ & 1.332 .214 & $-34 \%$ & 2.021 .391 & $-23 \%$ & 2.617 .154 & $7 \%$ & 2.450 .952 \\
\hline Empréstimos e financiamentos & 2.078 .668 & $253 \%$ & 589.509 & $-56 \%$ & 1.329 .461 & $-34 \%$ & 2.015 .320 & $-22 \%$ & 2.580 .625 & $7 \%$ & 2.409 .916 \\
\hline Outras Obrigações & 2.753 & $180 \%$ & 984 & $-64 \%$ & 2.753 & $-55 \%$ & 6.071 & $-83 \%$ & 36.529 & $-11 \%$ & 41.036 \\
\hline Patrimônio Líquido Consolidado & 201.288 & $-90 \%$ & 2.055 .646 & $-27 \%$ & 2.813.246 & $-4 \%$ & 2.926 .184 & $27 \%$ & 2.298 .663 & $1 \%$ & 2.269 .676 \\
\hline Capital Social Realizado & 2.377 & $-100 \%$ & 1.292 .377 & $0 \%$ & 1.292 .377 & $0 \%$ & 1.292 .377 & $16 \%$ & 1.114 .377 & $3 \%$ & 1.078 .236 \\
\hline Reservas de Lucro & 137.453 & $-67 \%$ & 421.714 & $-59 \%$ & 1.034 .007 & $-5 \%$ & 1.090 .154 & $-24 \%$ & 1.437 .911 & $23 \%$ & 1.173 .738 \\
\hline Lucros/Prejuízos Acumulados & -133.442 & - & 0 & - & 0 & - & 0 & - & 0 & - & 0 \\
\hline Ajustes de Avaliação Patrimonial & -193.802 & $-15 \%$ & -227.235 & $102 \%$ & -112.350 & $-19 \%$ & -138.837 & $-49 \%$ & -274.921 & $51 \%$ & -182.142 \\
\hline Participação dos acionistas não controladores & 388.702 & $-32 \%$ & 568.790 & $-5 \%$ & 599.212 & $-12 \%$ & 682.490 & $3105 \%$ & 21.296 & $-89 \%$ & 199.844 \\
\hline
\end{tabular}

Fonte: Elaborado pela autora a partir de dados do Relatório de Administração da AG

Além da análise vertical, é também necessário realizar a análise horizontal das demonstrações financeiras - que possui o intuito de examinar a evolução histórica de cada rubrica - para que seja possível identificar as linhas que apresentaram maiores alterações ao longo dos anos estudados. Olhando para o Ativo de forma geral percebe-se que este sofreu uma diminuição ao longo dos anos, pois de $R$ \$ 5.300 MM em 2012 passou para $R$ \$ 2.557 MM em 2017, o que representa um decréscimo de 52\%. Grande parte dessa queda foi em consequência da diminuição das rubricas Investimentos e Caixa e Bancos e apesar de a última ter mostrado uma diminuição percentual maior, a rubrica Investimentos teve uma queda mais acentuada em termos de valor, de quase $\mathrm{R} \$ 2 \mathrm{Bi}$. Isso já pode ser interpretado como uma consequência da diminuição da carteira de obras das empreiteiras envolvidas na Lava Jato, entre elas a Andrade Gutierrez, conforme citado anteriormente. Outra rubrica que, mesmo sem ser muito expressiva no montante geral, mas que apresentou uma queda significativa, entre 2012 e 2015, foi a linha de Contas e Receber, o que também mostra o efeito da diminuição de projetos por parte da construtora.

No Passivo, o que mais chama a atenção é a diminuição do Patrimônio Líquido, que de 2016 para 2017 sofreu uma queda de $90 \%$, passando de $R$ \$ $2.055 \mathrm{MM}$ para $\mathrm{R} \$ 201 \mathrm{MM}$ em 2017. Essa mudança ocorreu em grande parte porque os acionistas da companhia decidiram por diminuir o Capital Social da empresa, mas sem realizar o cancelamento de ações, segundo os seguintes trechos das Notas Explicativas da AG Participações de 2017:

No primeiro trimestre de 2017, os acionistas da Companhia deliberaram em Assembleia Geral Extraordinária, a redução do capital social da Companhia, no valor de $R \$ 800.000$, passando de $R \$ 1.292 .377$ para $R \$ 492.377$, sem cancelamento de ações, mantendo-se inalterado o percentual de participação dos acionistas no capital social da Companhia [...].

(ANDRADE GUTIERREZ PARTICIPAÇÕES SA, 2017, p. 46) 
No quarto trimestre de 2017, os acionistas da Companhia deliberaram em Assembleia Geral Extraordinária, a redução do capital social da Companhia no valor de $R \$ 490.000$, passando de $R \$ 492.377$ para $R \$ 2.377$ sem cancelamento de ações, mantendo-se inalterado o percentual de participação dos acionistas no capital social da Companhia [...].

(ANDRADE GUTIERREZ PARTICIPAÇÕES SA, 2017, p. 46)

Essa ação foi uma tentativa de trazer liquidez para a empresa e para as suas investidas, para que essas pudessem arcar com as suas obrigações de empréstimos e financiamentos, como mostra o seguinte trecho das Notas Explicativas de 2017 da companhia:

Em 31 de dezembro de 2017, a Companhia [Andrade Gutierrez] apresentou patrimônio líquido negativo de $R \$ 187.414$ e prejuízo de $R \$ 133.442$. Essa variação se deve, principalmente, pelos seguintes fatores: [...] e (iv) redução de capital da Companhia com o objetivo de disponibilizar liquidez financeira à Andrade Gutierrez S.A. e suas investidas, para fazer frente às obrigações com empréstimos, financiamentos e aportes em investidas da Companhia. (ANDRADE GUTIERREZ PARTICIPAÇÕES SA, 2017, p. 47)

Além disso, mostra-se válido ressaltar também a linha de Reserva de Lucros e Lucros/Prejuízos Acumulados, pois estas também contribuíram para a diminuição do Patrimônio Líquido. A primeira sofreu uma grande queda de 2012 para 2016, passando de $R \$$ 1.173 MM para menos de $\mathrm{R} \$ 150 \mathrm{MM}$ em 2017, um grande indicativo de queda no resultado da empreiteira, principalmente após 2014 (ano do início da Lava Jato). Já a rubrica de Lucros/Prejuízos Acumulados, apesar de zerada ao longo dos anos, apresentou resultado negativo (prejuízo) pela primeira vez em 2017 nos anos analisados.

Nota-se também um aumento de empréstimos do Passivo Não Circulante, que de 2016 para 2017 teve um aumento de 253\%, depois de apresentar queda de 2012 a 2016. Isto ocorreu devido à uma emissão de debêntures pela $A G$ Participações, no valor de $R$ \$1,6 Bi em dezembro de 2016 (PIRES, 2016). O intuito da empreiteira era de arcar com o pagamento de uma emissão de debêntures feita em 2012 - com vencimento de 10 anos - mas que com o rebaixamento de sua classificação de risco pela Standard \& Poor teve seu pagamento antecipado. Além disso, o aumento da inflação de 2012 a 2017 também fez com que o valor devido pela companhia fosse ainda maior do que o previsto, agravando a dificuldade da AG de honrar seus compromissos. (OLIVEIRA, 2017)

Ademais, outro demonstrativo que mostra-se válido analisar horizontalmente é o DRE, conforme a tabela 5 . 
Tabela 5 - Análise Horizontal do DRE

\begin{tabular}{|c|c|c|c|c|c|c|c|c|c|c|c|}
\hline \multirow{2}{*}{ (R\$ mil) } & \multicolumn{2}{|c|}{2017} & \multicolumn{2}{|c|}{2016} & \multicolumn{2}{|c|}{2015} & \multicolumn{2}{|c|}{2014} & \multicolumn{2}{|c|}{2013} & \multirow{2}{*}{$\begin{array}{c}2012 \\
\mathrm{R} \$\end{array}$} \\
\hline & $\mathrm{RST}$ & \% Horizontal & $\mathrm{R} \$$ & \% Horizonta & $\mathrm{RST}$ & \% Horizonta & $\mathrm{RST}$ & 6 Horizonta & $\mathrm{RSS}$ & $\%$ Horizonta & \\
\hline Receita de Bens e/ou Serviços & 103.164 & $6 \%$ & 97.012 & $8 \%$ & 89.797 & $6 \%$ & 84.591 & $102 \%$ & 41.865 & $-34 \%$ & 63.418 \\
\hline Custo dos Bens e/ou Serviços Vendidos & -70.995 & $9 \%$ & -65.116 & $20 \%$ & -54.100 & $9 \%$ & -49.469 & $117 \%$ & -22.815 & $4 \%$ & -21.940 \\
\hline Resultado Bruto & 32.169 & $1 \%$ & 31.896 & $-11 \%$ & 35.697 & $2 \%$ & 35.122 & $84 \%$ & 19.050 & $-54 \%$ & 41.478 \\
\hline Despesas/Receitas Operacionais & 57.495 & $-353 \%$ & -22.693 & $-105 \%$ & 450.206 & $30 \%$ & 346.671 & $-44 \%$ & 624.138 & $-21 \%$ & 794.959 \\
\hline Despesas Com Vendas & 0 & - & 0 & - & 0 & - & 0 & - & 0 & - & 0 \\
\hline Despesas Gerais e Administrativas & -54.906 & $-16 \%$ & -65.201 & $52 \%$ & -43.008 & $-48 \%$ & -82.306 & $22 \%$ & -67.620 & $-19 \%$ & -83.727 \\
\hline Outras Receitas Operacionais & 0 & - & 0 & - & 0 & - & 0 & - & 0 & - & 47.665 \\
\hline Outras Despesas Operacionais & 66.973 & $-133 \%$ & -201.288 & - & 0 & - & -106 & $-100 \%$ & -37.647 & - & 0 \\
\hline Resultado de Equivalência Patrimonial & 45.428 & $-81 \%$ & 243.796 & $-51 \%$ & 493.214 & $16 \%$ & 426.083 & $-42 \%$ & 729.405 & $-12 \%$ & 831.021 \\
\hline Resultados antes dos Resultados Financeiros e Tril & 89.664 & $874 \%$ & 9.203 & $-98 \%$ & 485.903 & $28 \%$ & 378.793 & $-41 \%$ & 643.188 & $-23 \%$ & 836.437 \\
\hline Resultado Financeiro & -394.533 & $121 \%$ & -178.251 & $-61 \%$ & -454.557 & $123 \%$ & -203.909 & $3 \%$ & -198.129 & $-33 \%$ & -296.915 \\
\hline Resultado Antes dos Tributos Sobre o Lucro & -304.869 & $80 \%$ & -169.048 & $-639 \%$ & 31.346 & $-82 \%$ & 174.884 & $-61 \%$ & 445.059 & $-18 \%$ & 539.522 \\
\hline Imposto de Renda e Contribuição Social Sobre o LU & -9.718 & - & 0 & - & 0 & - & 48.453 & $-9007 \%$ & -544 & $-78 \%$ & -2.450 \\
\hline Resultado Liquido das Operações Continuadas & -314.587 & $86 \%$ & -169.048 & $-639 \%$ & 31.346 & $-86 \%$ & 223.337 & $-50 \%$ & 444.415 & $-17 \%$ & 537.072 \\
\hline Lucro/Prejuízo Consolidado do Período & -314.587 & $86 \%$ & -169.048 & $-639 \%$ & 31.346 & $-86 \%$ & 223.337 & $-50 \%$ & 444.415 & $-17 \%$ & 537.072 \\
\hline
\end{tabular}

Em uma

Fonte: Elaborado pela autora a partir de dados do Relatório de Administração da AG primeira

análise, parece que a empresa não sofreu grandes mudanças, pois sua receita apresentou crescimento de 2012 para 2017. Porém, como trata-se de uma holding, é importante analisar a linha de Equivalência Patrimonial. De acordo com Silva (2017), sempre que uma empresa tem participação em outra companhia, deve reconhecer seu lucro - ou prejuízo - nas suas demonstrações financeiras, por meio da rubrica de Resultado de Equivalência Patrimonial. Dessa forma, "quando o resultado da equivalência patrimonial for positivo, isso indica que está havendo lucro na empresa na qual foi feito o investimento, ao mesmo tempo que equivalência patrimonial negativa significa prejuízo da empresa investida". (SILVA, 2017, p. 135) Assim sendo, observando a rubrica de Equivalência Patrimonial percebe-se uma significativa piora no resultado obtido pelas investidas e, consequentemente, pela holding.

Segundo as Notas Explicativas de 2017 da AG Participações essa grande queda de 2016 para 2017 nesta linha de seu DRE ocorreu porque o resultado da CEMIG deixou de ser contabilizado como um investimento e passou a ser reclassificado como ativo financeiro. Isso se deu porque a AGC Energia (investida da AG Concessões, principal investida da AG Participações), rompeu acordo de acionista com a CEMIG e colocou suas ações à venda na bolsa de valores (Jornal do Comércio, 2017). Esse movimento teve início em 2016 e teve fim no quarto trimestre de 2017, quando a AGC Energia vendeu a totalidade de ações ordinárias que detinha da companhia, segundo as Notas Explicativas da AG Participações de 2017. Com isso, o objetivo da AG era de gerar fluxo de caixa para arcar com suas obrigações, já que a diminuição de seus contratos gerou uma queda em seu caixa. (Jornal do Comércio, 2017)

Por fim, como resultado da significativa queda do resultado de equivalência patrimonial, percebe-se uma grande piora no lucro líquido da AG, que passou a apresentar resultado negativo a partir de 2016, dois anos após o início da Lava Jato e ano em que o antigo 
presidente da empreiteira, Otávio de Azevedo, foi condenado pelos crimes de corrupção, lavagem de dinheiro e participação em organização criminosa. (FONSECA, 2016)

O gráfico 1 mostra a evolução dessas duas rubricas - lucro líquido e resultado de equivalência patrimonial - ao longo dos seis anos estudados.

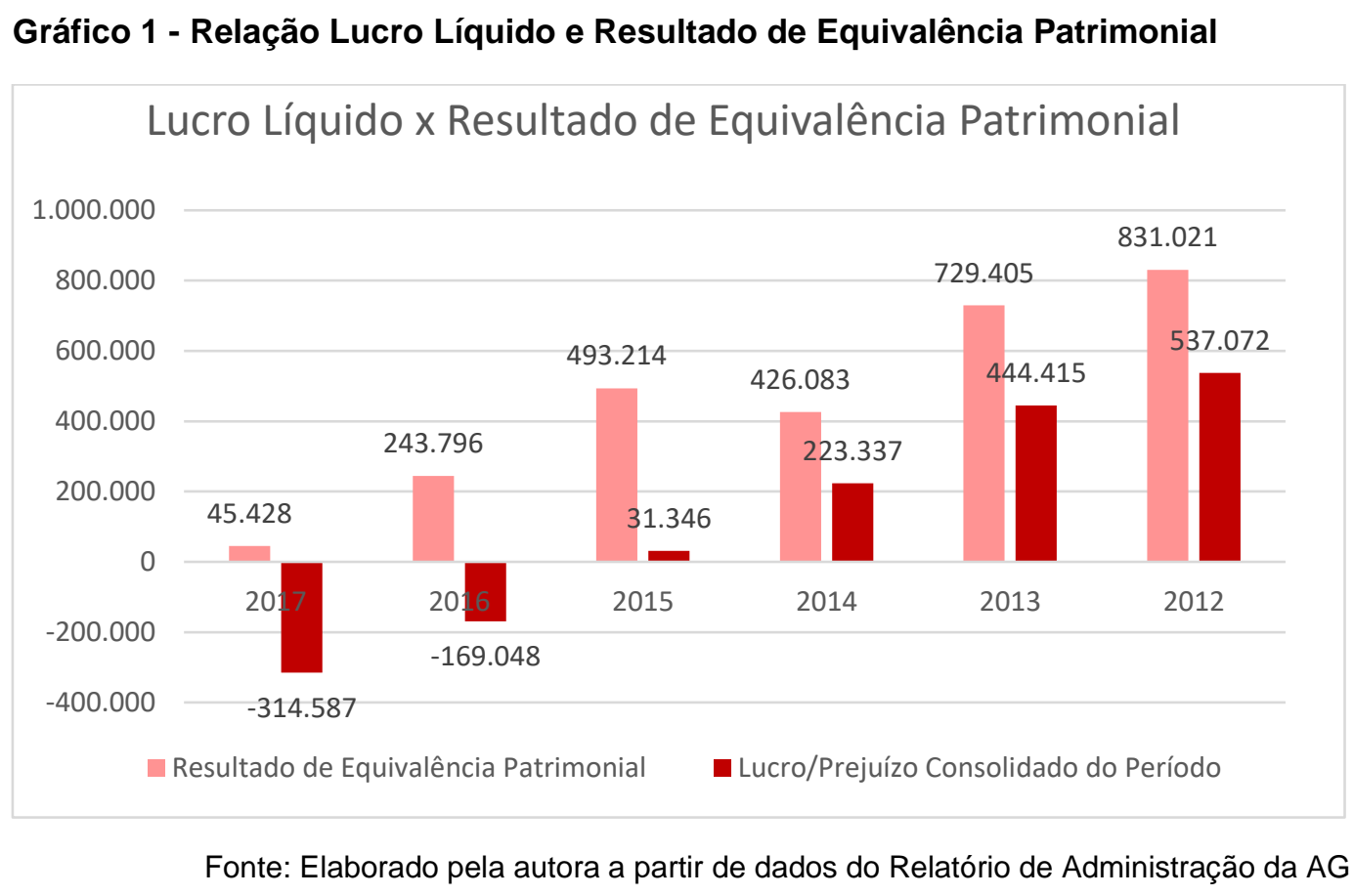

\subsection{Indicadores de Liquidez}

Tabela 6 - Indicadores de Liquidez

\begin{tabular}{|lcccccc|}
\hline \multicolumn{1}{l}{$\begin{array}{c}\text { Indicador } \\
\text { Liquidez }\end{array}$} & $\mathbf{2 0 1 7}$ & $\mathbf{2 0 1 6}$ & $\mathbf{2 0 1 5}$ & $\mathbf{2 0 1 4}$ & $\mathbf{2 0 1 3}$ & $\mathbf{2 0 1 2}$ \\
\hline Liquidez geral & & & & & & \\
Liquidez corrente & 0,22 & 0,32 & 0,64 & 0,47 & 0,28 & 0,44 \\
Liquidez imediata & 1,75 & 0,55 & 1,76 & 2,28 & 2,50 & 2,26 \\
\hline
\end{tabular}

Fonte: Elaborado pela autora a partir de dados do Relatório de Administração da AG

Como previamente explicado, os indicadores de liquidez mostram a capacidade da empresa de arcar com as suas dívidas. Analisando a liquidez geral, percebe-se que esse indicador, mesmo em 2012, já era menor que 1, indicando que para cada $R \$ 1,00$ de dívida, ela possuía apenas $R \$ 0,44$ de haveres no ativo, o que não inspira muita segurança. Porém, em 2017 esse indicador caiu pela metade, sendo agora 0,22, mesmo passando por uma 
melhora em 2015, quando atingiu 0,64. Essa queda em 2017 se deu, principalmente, pela diminuição do Ativo e pelo aumento do Passivo Exigível, pela nova emissão de debêntures necessária para arcar com o adiantamento de uma emissão anterior, como citado anteriormente - deixando a empresa em uma situação pouco confortável se tratando de sua liquidez geral.

A liquidez corrente da Andrade Gutierrez, isto é, liquidez que leva em consideração as contas de curto prazo - tanto no Ativo como no Passivo - mostrou uma significativa piora de 2012 para 2016, passando de 2,26 para 0,55. Em 2012 a companhia possuía capacidade de pagar mais do que o dobro de suas obrigações de curto prazo, o que passava ao mercado uma segurança em emprestar dinheiro à empreiteira. Em 2016, no entanto, esse indicador passou a ser menor do que 1, ano também em que a AG teve seu nível de risco rebaixado, conforme citado anteriormente. Além disso, em 2016, a empreiteira também teve a antecipação do vencimento de debêntures emitidas em 2012, o que aumentou seu passivo de curto prazo, influenciando este indicador. Atualmente, porém, observa-se uma melhora neste índice, que está em 1,75, resultado que pode ser atribuído ao leve aumento do Ativo Circulante, principalmente à rubrica Caixa e Bancos, e à diminuição do Passivo Circulante. No entanto, apesar dessa expressiva melhora, mostra-se válido destacar que no ano de 2018 a AG teve sua classificação de risco rebaixada novamente, dessa vez pela Moody's, uma das grandes empresas de serviços financeiros dos Estados Unidos.

Em relação à liquidez imediata, indicador que analisa a capacidade de uma empresa de arcar com suas dívidas apenas com o que dispõe na rubrica de Caixa e Bancos, como já era de se esperar e seguindo os demais indicadores de liquidez, apresentava um bom número no ano de 2012, de 1,55, e foi caindo ao longo dos anos, chegando a 0,41 no ano de 2016. Tratase de um reflexo da diminuição de sua linha de Disponíveis, consequência da contração da sua carteira de obras e projetos.

\subsection{Indicadores de Rentabilidade e Lucratividade}

Tabela 7 - Indicadores de Rentabilidade e Lucratividade

\begin{tabular}{|c|c|c|c|c|c|c|}
\hline Indicador & 2017 & 2016 & 2015 & 2014 & 2013 & 2012 \\
\hline \multicolumn{7}{|c|}{ Rentabilidade e Lucratividade } \\
\hline $\mathrm{ROE}$ & $-156 \%$ & $-8 \%$ & $1 \%$ & $8 \%$ & $19 \%$ & $24 \%$ \\
\hline ROA & $-12 \%$ & $-5 \%$ & $1 \%$ & $4 \%$ & $8 \%$ & $10 \%$ \\
\hline Margem líquida & $-305 \%$ & $-174 \%$ & $35 \%$ & $264 \%$ & $1062 \%$ & $847 \%$ \\
\hline
\end{tabular}

Fonte: Elaborado pela autora a partir de dados do Relatório de Administração da AG 
Os indicadores de rentabilidade e lucratividade têm um papel importante em análises financeiras, pois são eles que indicam o quanto de retorno o investidor está efetivamente recebendo do empreendimento em que está investindo. Dessa forma, a melhor maneira de analisa-los é por meio da comparação com outros empreendimentos do mesmo segmento, para que se possa compreender se a empresa analisada está trazendo retornos mais, ou menos, atrativos que seus concorrentes. Assim sendo, foram calculados os indicadores de rentabilidade e lucratividade de 2012 e 2013 - anos anteriores à Lava Jato - da Queiroz Galvão (QG), outra grande construtora envolvida nos escândalos e investigações.

\section{Tabela 8 - Indicadores de Rentabilidade e Lucratividade da Queiroz Galvão}

\begin{tabular}{|ccc|}
\hline & Queiroz Galvão & \\
\hline Indicador & $\mathbf{2 0 1 3}$ & $\mathbf{2 0 1 2}$ \\
\hline ROE & $9 \%$ & $4 \%$ \\
ROA & $54 \%$ & $9 \%$ \\
Margem Líquida & $40 \%$ & $18 \%$ \\
\hline
\end{tabular}

Fonte: Elaborado pela autora a partir de dados do Relatório de Administração da QG

O primeiro indicador calculado, o ROE, mostra o retorno que cada $R \$ 1,00$ investido traz ao acionista. Em 2012 e 2013, a Andrade Gutierrez apresentava um ROE atrativo, principalmente se comparado ao da Queiroz Galvão, pois em 2012 a AG apresentou um retorno de $R \$ 0,24$ para cada $R \$ 1$ real investido por seus acionistas, enquanto a $Q G$ trouxe apenas $R \$ 0,04$ para cada $R \$ 1$ investido. No ano de 2013, apesar de o ROE da AG ter apresentado uma leve queda, chegando a $R \$ 0,19$, ainda era bem mais atrativo do que o da QG, mesmo este sofrendo um aumento de mais de 100\% de 2012 para 2013, e chegando a $\mathrm{R} \$$ 0,09. A partir de 2014, porém, o ROE da empreiteira estudada começou a cair significativamente até que, em 2016, passou a apresentar retornos negativos, cenário que se manteve em 2017, com um retorno de $R \$-0,08$ e $-R \$ 1,56$ respectivamente.

Outro indicador explorado, o ROA, mede o quanto de retorno o acionista obtém para cada $R \$ 1$ do ativo da companhia. Em relação à Andrade Gutierrez, se comparada à sua concorrente Queiroz Galvão, já não apresentava indicadores tão atrativos. Em 2012 seu ROA - de $R \$ 0,10$ - era semelhante ao da $Q G$ - de $R \$$ 0,09 - mas em 2013 a Queiroz Galvão passou a apresentar um ROA de $R \$ 0,54$ enquanto o indicador da $A G$ caiu para $R \$ 0,08$. Após o início da Lava Jato esse cenário piorou e o ROA da empreiteira continuou a cair, até passar a ser negativo, também em 2016, e alcançando o patamar de $\mathrm{R} \$-0,12$ em 2017. Em outras palavras, para cada $R \$ 1$ investido no ativo da companhia, o acionista teve um prejuízo de $R \$ 0,12$. 
Além do ROE e do ROA, outro indicador de extrema importância é a margem líquida, pois esta avalia a eficiência operacional de um empreendimento e é calculado a partir da divisão do lucro líquido pela receita líquida, conforme mencionado no capítulo 2. Verificando a margem líquida da Andrade Gutierrez em comparação à Queiroz Galvão, observa-se que a primeira possui uma eficiência operacional muito maior do que a segunda, já que em 2012 este indicador da AG girava em torno de 8 enquanto que o número da QG não chegava a 0,20. Assim sendo, pode-se dizer que antes da Operação Lava Jato a empreiteira possuía uma margem bastante competitiva, mostrando uma boa eficiência em suas operações e uma boa rentabilidade.

A partir de 2014, porém, esse índice começou a cair e, assim como os demais indicadores da companhia, passou a apresentar resultado negativos a partir de 2016, um dos anos mais complicados enfrentados pela AG desde 2012. Atualmente este índice encontrase em -3, o que representa uma queda de mais de $100 \%$ se comparado ao ano de 2012 . No entanto, como parte considerável do resultado da AG provém do Resultado de Equivalência Patrimonial, esse indicador pode não refletir inteiramente a realidade, pois considera apenas a receita líquida do empreendimento para seu cálculo, não sendo então relevante para esse estudo.

De modo geral, é possível observar que até o ano de 2016, mas principalmente 2014, a Andrade Gutierrez apresentava indicadores atrativos para os acionistas e que retratavam uma boa administração. Porém, a partir de 2016 a companhia deixou de ser rentável para seus investidores.

\subsection{Indicadores de Estrutura de Capital}

Tabela 9 - Indicadores de Estrutura de Capital

\begin{tabular}{|lcccccc|}
\hline \multicolumn{1}{c}{ Indicador } & $\mathbf{2 0 1 7}$ & $\mathbf{2 0 1 6}$ & $\mathbf{2 0 1 5}$ & $\mathbf{2 0 1 4}$ & $\mathbf{2 0 1 3}$ & $\mathbf{2 0 1 2}$ \\
\hline Estrutura de Capital & & & & & & \\
\hline Índice de participação de terceiros & $92,13 \%$ & $39,16 \%$ & $42,27 \%$ & $46,54 \%$ & $56,14 \%$ & $57,33 \%$ \\
Composição do endividamento & $11,65 \%$ & $55,37 \%$ & $35,33 \%$ & $20,64 \%$ & $11,05 \%$ & $19,64 \%$ \\
Grau de endividamento & 11,70 & 0,64 & 0,73 & 0,87 & 1,28 & 1,34 \\
Grau de alavancagem financeira & 12,70 & 1,64 & 1,73 & 1,87 & 2,28 & 2,34 \\
\hline
\end{tabular}

Fonte: Elaborado pela autora a partir de dados do Relatório de Administração da AG

Os indicadores de estrutura de capital analisam as origens dos financiamentos de empresas, que podem ser próprios ou provenientes de terceiros. O primeiro deles, o índice de participação de terceiros, mostra o quanto dessa estrutura provém de terceiros. No caso da Andrade Gutierrez há uma enorme discrepância entre os cinco primeiros anos analisados 
e o ano de 2017. Em 2012, a companhia contava com pouco mais da metade de sua estrutura de capital proveniente de terceiros, 57\%, mostrando um equilíbrio entre as duas formas de financiamento por parte da companhia. Em 2017, no entanto, esse percentual saltou para mais de $90 \%$. Esse número é uma consequência da diminuição do patrimônio líquido da empresa, no ano de 2016 para 2017, assim como o aumento na rubrica de empréstimos e financiamentos. Dessa forma, pode-se dizer que como estratégia a empresa optou por diminuir o capital próprio e usar o capital de terceiros para alavancar suas operações. Essa atitude, porém, deve ser analisada com cautela, pois na situação da Andrade Gutierrez, onde a empresa já sofreu dois rebaixamentos de classificação de risco, esses empréstimos podem vir com altos juros embutidos e os quais a AG pode encontrar dificuldades para pagar no futuro.

A composição do endividamento, por outro lado, indica que grande parte dessas dívidas - cerca de $90 \%$ - deverão ser quitadas no longo prazo, o que pode ser uma suavização de sua situação, dando tempo de a empresa melhorar seu desempenho e conseguir arcar com essas obrigações no futuro. Ainda analisando este índice, percebe-se que em 2016 este atingiu seu valor mais alto nos 5 anos estudados, ano em que a AG teve mais da metade de suas obrigações com financiamento vencendo no curto prazo.

Já o grau de endividamento aponta o quanto a empresa tomou emprestado para cada $\mathrm{R} \$ 1$ próprio. Como era de se esperar, esse indicador teve um enorme salto de 2016 para 2017, ano em que a Andrade Gutierrez diminuiu seu capital social, aumentando a participação do capital de terceiros e, consequentemente, aumentando o seu grau de endividamento, que pulou de 1,34 em 2012 para 11,70 em 2017, tendo seu valor mais baixo em 2016.

O grau de alavancagem financeira mostra o quanto o capital de terceiros pode elevar os resultados do empreendimento. De acordo com o que foi observado anteriormente, a Andrade Gutierrez optou por aumentar o capital de terceiros, provavelmente com o intuito de aumentar e melhorar o seu resultado líquido. Dessa forma, o aumento exorbitante desse indicador, que girava em torno de 2 de 2012 a 2015, cresceu mais de dez vezes, chegando ao valor de 12,70, confirmando a suspeita de que a empresa passou a usar como estratégia, pelo menos a partir de 2017, a alavancagem financeira. Mostra-se válido ressaltar que o valor mais baixo deste índice, assim como os demais indicadores analisados, foi no ano de 2016. 


\subsection{Fator de Insolvência}

Tabela 10 - Fator de Insolvência

\begin{tabular}{|lllllll|}
\hline Indicador & $\mathbf{2 0 1 7}$ & $\mathbf{2 0 1 6}$ & $\mathbf{2 0 1 5}$ & $\mathbf{2 0 1 4}$ & $\mathbf{2 0 1 3}$ & $\mathbf{2 0 1 2}$ \\
\hline Fator de Insolvência & 0,78 & 1,68 & 5,20 & 6,18 & 6,28 & 5,92 \\
\hline
\end{tabular}

Fonte: Elaborado pela autora a partir de dados do Relatório de Administração da AG

Figura 5 - Termômetro de Kanitz da Andrade Gutierrez

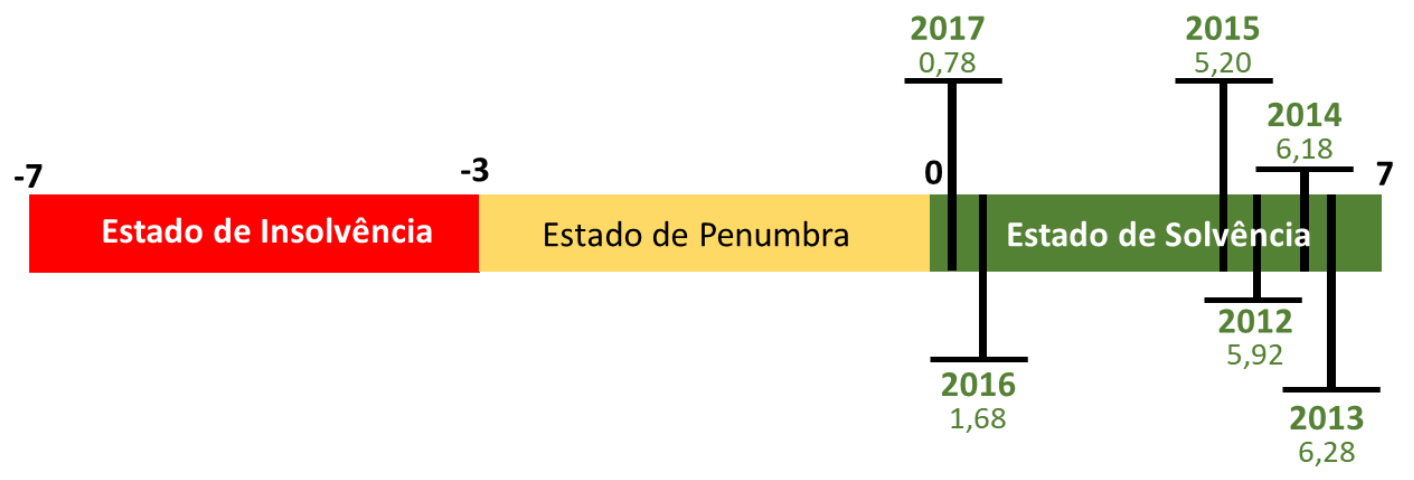

Fonte: Elaborado pela autora a partir de dados do Relatório de Administração da AG

Por fim, o último indicador a ser analisado neste estudo é o fator de insolvência, desenvolvido por Stephen Kanitz, que aponta a propensão da empresa à falência. Observando os números da Andrade Gutierrez é possível perceber que a empreiteira possuía um forte estado de solvência em 2012, tendo um fator de insolvência de 5,92, número próximo à 7 , valor máximo do termômetro. Esse cenário se manteve até 2015, quando o indicador sofreu uma queda brusca e, atualmente, em 2017, passou a apresentar um resultado preocupante de 0,78.

De acordo com o termômetro de Kanitz, ao ficar entre 0 e -3, a empresa encontra-se no estado de penumbra, estágio entre a solvência e a insolvência. No caso da Andrade Gutierrez, caso sua situação não seja revertida, ela pode estar caminhando para o estado de penumbra e, em um cenário pessimista, para a insolvência. Assim, caso este indicador não seja melhorado, a AG Participações pode vir a falir futuramente. Porém, seu atual cenário, apesar de preocupante, ainda não indica este destino. 


\section{Conclusões}

\subsection{Conclusão}

O objetivo principal desse estudo era de analisar se o envolvimento de uma empresa em um dos maiores escândalos de corrupção do Brasil, teria impacto em seu desempenho e, consequentemente, em seus indicadores financeiros. Apesar de o intuito inicial ser de realizar o estudo com a Odebrecht, empreiteira protagonista da Lava Jato, as informações disponíveis acerca dessa companhia limitariam as análises necessárias e, assim sendo, optou-se por estudar a Andrade Gutierrez, empreiteira brasileira que já ocupou o lugar de segunda maior construtora do país. A partir do cálculo e análise de indicadores financeiros da AG foi possível ter uma visão geral do desempenho da empreiteira de 2012 a 2017.

De modo geral, o que mais chama a atenção na análise da Andrade Gutierrez Participações é a sua significativa piora em seu desempenho a partir de 2014 - ano do início da Operação Lava Jato e investigação das empreiteiras - mas, principalmente a partir de 2016, quando o ex-presidente da companhia foi preso, confirmando o envolvimento da empresa nos esquemas de corrupção. Esse cenário fica claro ao analisar o lucro líquido da AG, que no ano de 2016 deixou de ser positivo e passou a contar como prejuízo para a empreiteira de $\mathrm{R} \$ 169 \mathrm{MM}$.

Como resultado da condenação e do envolvimento da construtora na Lava Jato, a companhia sofreu uma significativa queda na sua carteira de obras, o que teve como consequência a diminuição no seu caixa e, ainda, nas suas contas a receber. A contração nos indicadores de liquidez reforça esse cenário, onde a liquidez geral caiu de 0,44 em 2012 para 0,22 em 2017. Com isso, a empresa passou a encontrar dificuldades em arcar com suas obrigações e a continuar com suas operações. Além disso, outro agravante e, provavelmente efeito dessa sequência de fatos, foi o rebaixamento da classificação de risco pela Standard \& Poor e o pagamento antecipado das debêntures emitidas em 2012 pela AG, ambos em 2016, acentuando ainda mais a situação precária da empreiteira. Mostra-se válido ressaltar que grande parte dos indicadores financeiros tiveram seu pior desempenho em 2016.

Para reverter a situação descrita, a Andrade Gutierrez buscou por formas de aumentar seu fluxo de caixa. Primeiro, por meio da emissão de debêntures em 2016, o que elevou seus indicadores de endividamento. E, ainda, pela diminuição do seu Patrimônio Líquido, conforme citado previamente. Com isso, o grau de endividamento da empresa chegou a 11,70 em 2017. Essas duas ações mostram um movimento da empreiteira para tentar se recuperar e sobreviver.

Por fim, pode-se então concluir que o envolvimento na Operação Lava Jato teve sim efeitos negativos no desempenho da Andrade Gutierrez, empresa atuante no ramo central 
das investigações. Além dos indicadores previamente citados, a queda do $\mathrm{ROE}$, de $\mathrm{R} \$ 0,24$ em 2012 para $R \$-1,56$ em 2017 e do $R O A$ de $R \$ 0,10$ em 2012 para $R \$-0,12$ em 2016, assim como a diminuição brusca do fator de insolvência - de 5,92 em 2012 para 0,78 em 2017 corroboram com essa conclusão.

\subsection{Sugestão e recomendação para novos estudos}

Apesar de esse estudo já ter possibilitado perceber que houve um impacto negativo no desempenho da Andrade Gutierrez, não foi possível concluir sobre o destino final da empreiteira, já que a operação Lava Jato ainda está em curso. Além disso, as atitudes para reverter o quadro da empresa ainda estão recentes, não sendo possível identificar seus resultados.

Embora a Andrade Gutierrez esteja ainda em busca de sua sobrevivência mostra-se válido ressaltar que no ano de 2018 ela já deixou de arcar com uma dívida de $R \$ 1,35$ bi e que ela se comprometeu a pagar uma multa de $\mathrm{R} \$ 1$ bi devido ao seu envolvimento em corrupção, lavagem de dinheiro e formação de cartel.

Assim sendo, o futuro da companhia ainda é incerto e recomenda-se que seja feito um novo estudo, quando a operação Lava Jato chegar ao fim, com o intuito de apurar o estado da Andrade Gutierrez e se esta foi capaz de sobreviver ao envolvimento neste escândalo. 


\section{Referências Bibliográficas}

ASSAF NETO, Alexandre. Estrutura e análise de balanços: um enfoque econômicofinanceiro. 10ª edição. São Paulo: Atlas, 2012.

BANQUIERI, Rogério; ROSA, Fábio; OTAVIO, Hector. Linha do tempo da Lava Jato. G1, Rio de Janeiro, 4 set. 2015 atualizado em 23 nov. 2017. Disponível em:<http://especiais.g1.globo.com/politica/2015/lava-jato/linha-do-tempo-da-lava-jato/>.

Acesso em: 4 de dezembro de 2017.

BM\&F BOVESPA. Empresas com registro cancelado. Disponível na internet:<http://bvmf.bmfbovespa.com.br/cias-Listadas/empresas-com-registrocancelado/DetalheEmpresasComRegistroCancelado.aspx?codigo=ODBE\&idioma=pt-br $>$. Acesso em 14 de outubro de 2018

BOM DIA BRASIL. Andrade Gutierrez pede desculpas por corrupção e vai pagar R\$ 1 bilhão. G1, 9 mai. 2016. Disponível em:<http://g1.globo.com/bom-diabrasil/noticia/2016/05/andrade-gutierrez-pede-desculpas-por-corrupcao-e-vai-pagar-r-1bilhao.html>. Acesso em 15 de outubro de 2018.

BRIGHAM, Eugene F.; HOUSTON, Joel F. Fundamentos da moderna administração financeira. 2 ed. São Paulo. Campus, 1999

COUTINHO, Leonardo. Os números colossais da operação Lava Jato. Veja, 17 jan. 2017. Disponível em: <https://veja.abril.com.br/brasil/os-numeros-colossais-da-operacaolava-jato/>. Acesso em: 30 de novembro de 2017.

DIONÍSIO, Bibiana. PF estima que prejuízo da Petrobras com corrupção poder ser de $\mathbf{R} \$ 42$ bi. G1, Paraná, 12 nov. 2015. Disponível em:<http://g1.globo.com/pr/parana/noticia/2015/11/pf-estima-que-prejuizo-da-petrobras-comcorrupcao-pode-ser-de-r-42-bi.html>. Acesso em 5 de dezembro de 2017.

DUARTE, Lidiane. Mensalão. InfoEscola, Disponível em: <https://www.infoescola.com/politica/mensalao/>. Acesso em 30 de novembro de 2017. 
ÉPOCA. Lava Jato: PF prende ex-diretor da Petrobras e executivos de empreiteiras. 14 nov. 2014. Disponível em:<https://epoca.globo.com/tempo/ noticia/2014/11/lava-jato-pf-prende-ex-diretor-da-bpetrobrasb-e-executivos-deempreiteiras.html>. Acesso em 14 de outubro de 2018.

ESTADÃO CONTEÚDO. Sem conseguir honrar dívida, Andrade Gutierrez tenta fechar novo acordo com credores. Época Negócios, 10 jul. 2018. Disponível em:<https://epocanegocios.globo.com/Empresa/noticia/ 2018/07/sem-conseguir-honrardivida-andrade-gutierrez-tenta-fechar-novo-acordo-com-credores.html>. Acesso em 14 de outubro de 2018.

FERNANDES, Cláudio. Impeachment de Fernando Collor. Mundo Educação. Disponível em:< http://mundoeducacao.bol.uol.com.br/historiadobrasil/impeachmentfernando-collor.htm>. Acesso em 29 de novembro de 2017.

FOLHA DE SÃO PAULO. Operação Lava Jato. Disponível na internet: http://arte.folha.uol.com.br/poder/operacao-lava-jato/\#capitulo8. Acesso em 5 de dezembro de 2017.

FONSECA, Pedro. Ex-presidente da Andrade Gutierrez é condenado a 18 anos de prisão; vai cumprir pena em casa. Reuters. 19 set. 2016. Disponível em:< https://br.reuters.com/article/businessNews/idBRKCN11Q016 acessada em 28/10/18>. Acesso em: 28 de outubro de 2018

G1. Ex-presidente da Andrade Gutierrez condenado no Rio a prisão domiciliar. Rio de Janeiro, 19 set. 2016. Disponível em:<http://g1.globo.com/politica/operacao-lavajato/noticia/2016/09/ex-presidente-do-grupo-andrade-gutierrez-e-condenado-no-rio.html>. Acesso em 14 de outubro de 2018.

JORNAL DO COMERCEIO. Operação Lava Jato força empreiteiras a mudarem rota para sobreviver. Porto Alegre, 02 mar. 2017. Disponível em:<https://www.jornaldocomercio.com/ conteudo/2017/02/cadernos/jc logistica/548380operacao-lava-jato-forca-empreiteiras-a-mudarem-rota-para-sobreviver.html>. Acesso em: 28 de outubro de 2018 
KASSAI, José Roberto; KASSAI, Silvia. Desvendando o termômetro de insolvência de Kanitz. ENCONTRO DA ASSOCIAÇÃO NACIONAL DE PÓS-GRADUAÇÃO E PESQUISA EM ADMINISTRAÇÃO, v. 22, 1998.

MARION, José Carlos. Contabilidade Empresarial. 16ª edição. São Paulo: Editora Atlas, 2012.

O GLOBO. Todas as fases da operação Lava Jato, ago. 2017. Disponível na internet: https://infograficos.oglobo.globo.com/brasil/todas-as-fases-da-operacao-lava-jato.html. Acesso em 29 de novembro de 2017.

OLIVEIRA, Fausto. Andrade Gutierrez volta a obter crédito. Construção Latino Americana. 10 jan. 2017. Disponível em:<https://www.construcaolatinoamericana.com/ noticias/andrade-gutierrez-volta-a-obter-credito/124233.article $>$. Acesso em: 28 de outubro de 2018

ORO, leda Margarete; BEUREN, Ilse Maria; HEIN, Nelson. Análise da relação entre a estrutura de capital e o lucro operacional nas diversas gerações de empresas familiares brasileiras. Contabilidade Vista \& Revista, v. 20, n. 1, 2009

PAVANELI, Aline. Lava Jato completa quatro anos com 40 sentenças de Sérgio Moro; tempo médio de trâmites das ações foi de nove meses. Paraná RPC, G1. Paraná, 17 mar. 2018. Disponível em:<https://g1.globo.com/pr/parana/noticia/lava-jato-completaquatro-anos-com-40-sentencas-de-sergio-moro-tempo-medio-de-tramite-das-acoes-foi-denove-meses.ghtml>. Acesso em 15 de outubro de 2018.

PIRES, Fernanda. Andrade Gutierrez aprova emissão de R\$ 1,6 bi em debêntures. Valor Econômico. 28 dez. $2016 . \quad$ Disponível em:<https://www.valor.com.br/empresas/4820488/andrade-gutierrez-aprova-emissao-de-r16-bi-em-debentures>. Acesso em: 28 de outubro de 2018.

ROSS, Stephen A.; WESTERFIELD, Randolph W.; JORDAN, Bradford D. Fundamentos de administração financeira. 9ª edição. Porto Alegre: Editora AMGH Editora LTDA. 
SILVA, José Pereira da. Análise Financeira das Empresas. 13a edição. São Paulo: Cengage Learning, 2017.

SILVA, Thamires O. Operação Lava Jato; Brasil Escola. Disponível em: $<$ http://brasilescola.uol.com.br/brasil/operacao-lava-jato.htm>. Acesso em 6 de dezembro de 2017

SOUZA, N. Posto que deu origem à operação Lava Jato deve mais de $\mathbf{R} \mathbf{8} \mathbf{\text { milhões }}$ à União. Uol Notícias, São Paulo, 1 jan. 2017. Disponível em:<https://noticias.uol.com.br/politica/ultimas-noticias/2017/08/01/posto-que-deu-origem-aoperacao-lava-jato-deve-mais-de-r-8-milhoes-a-uniao.htm>. Acesso em: 4 de dezembro de 2017. 


\section{Anexos}

7.1. Balanço Patrimonial Andrade Gutierrez 2012, 2013 e 2014

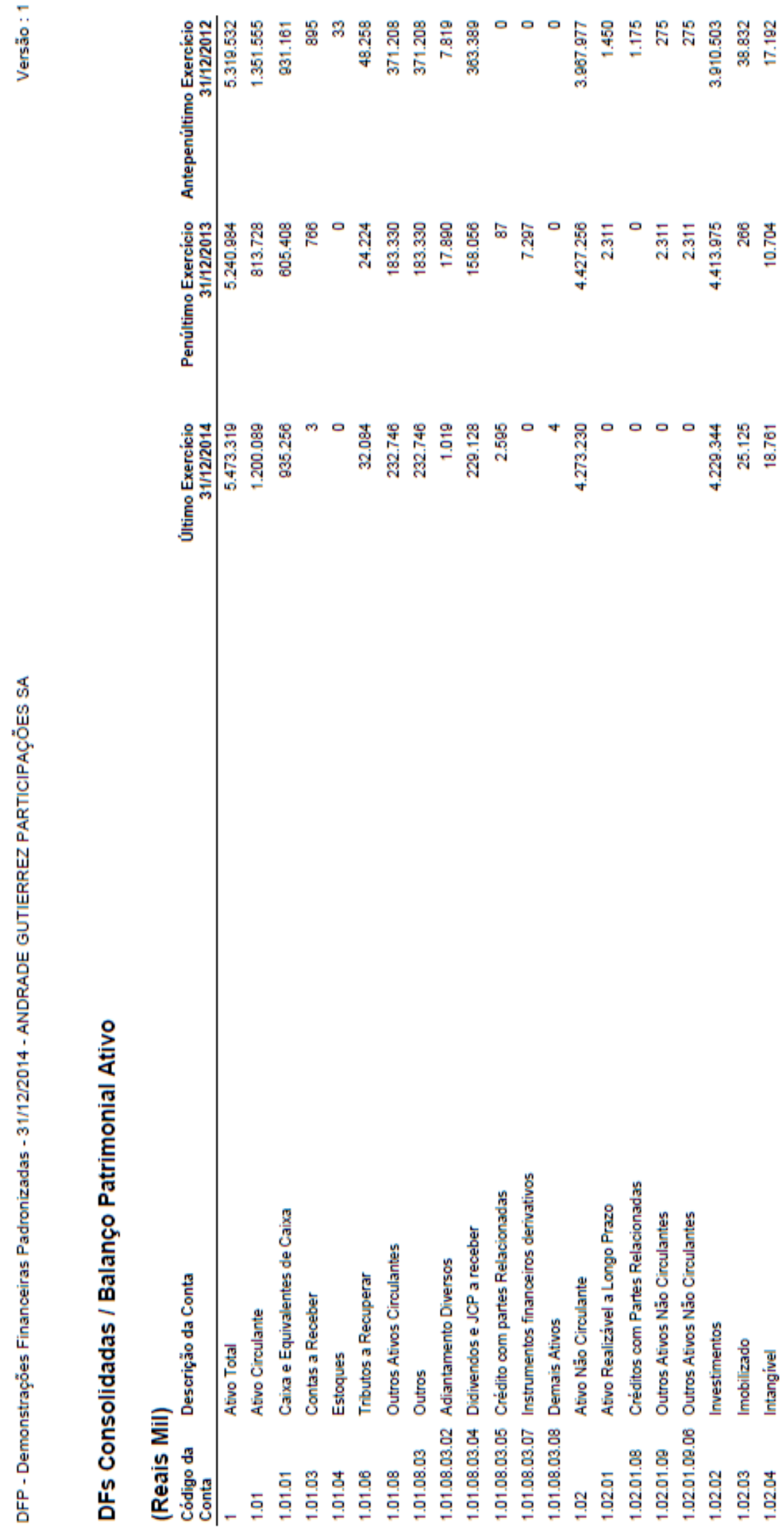




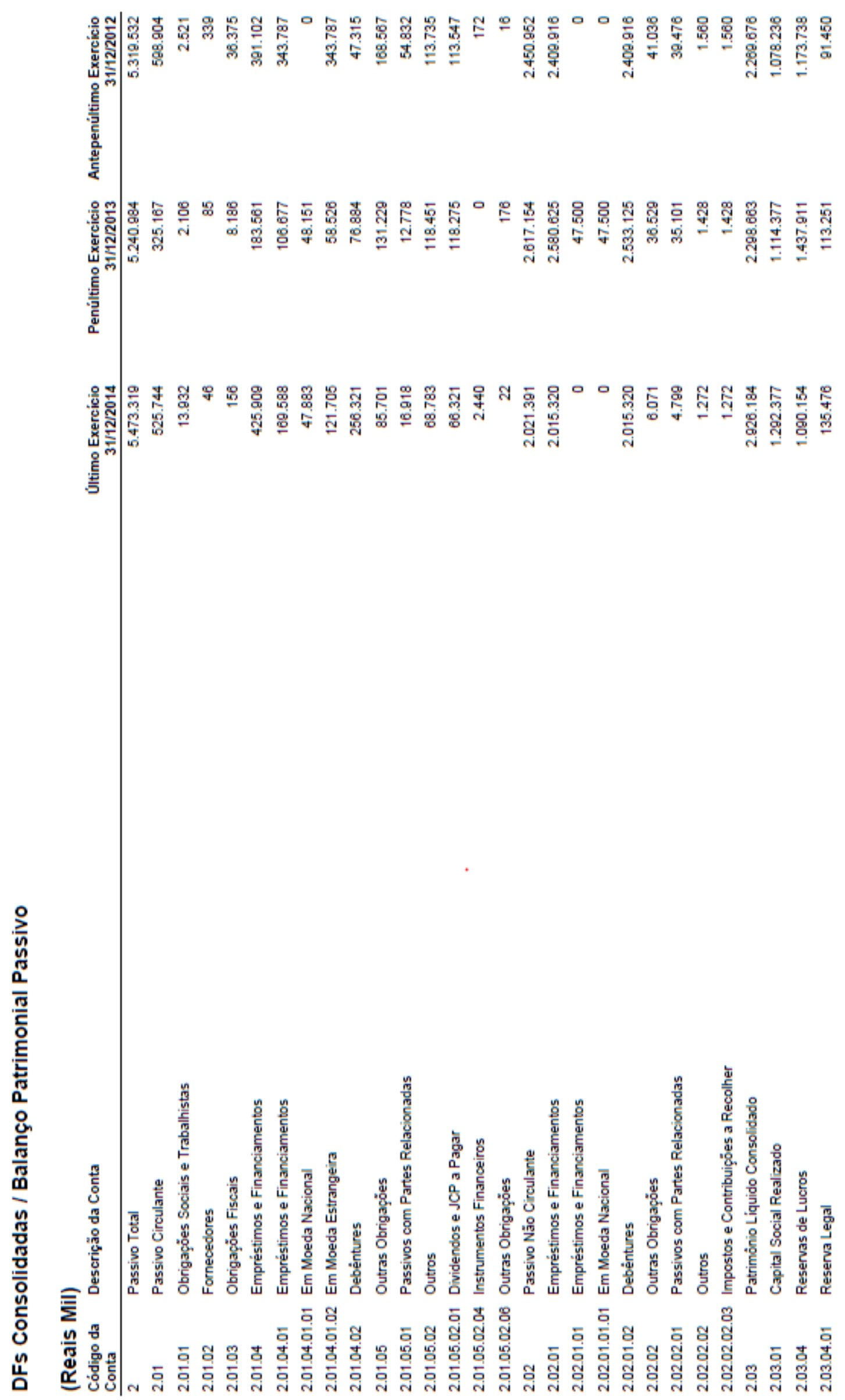




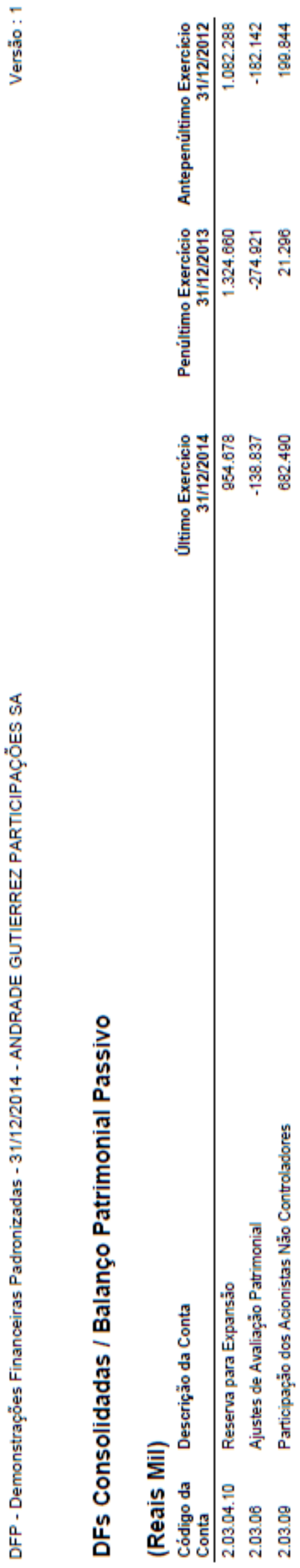


7.2. DRE Andrade Gutierrez 2012, 2013 e 2014

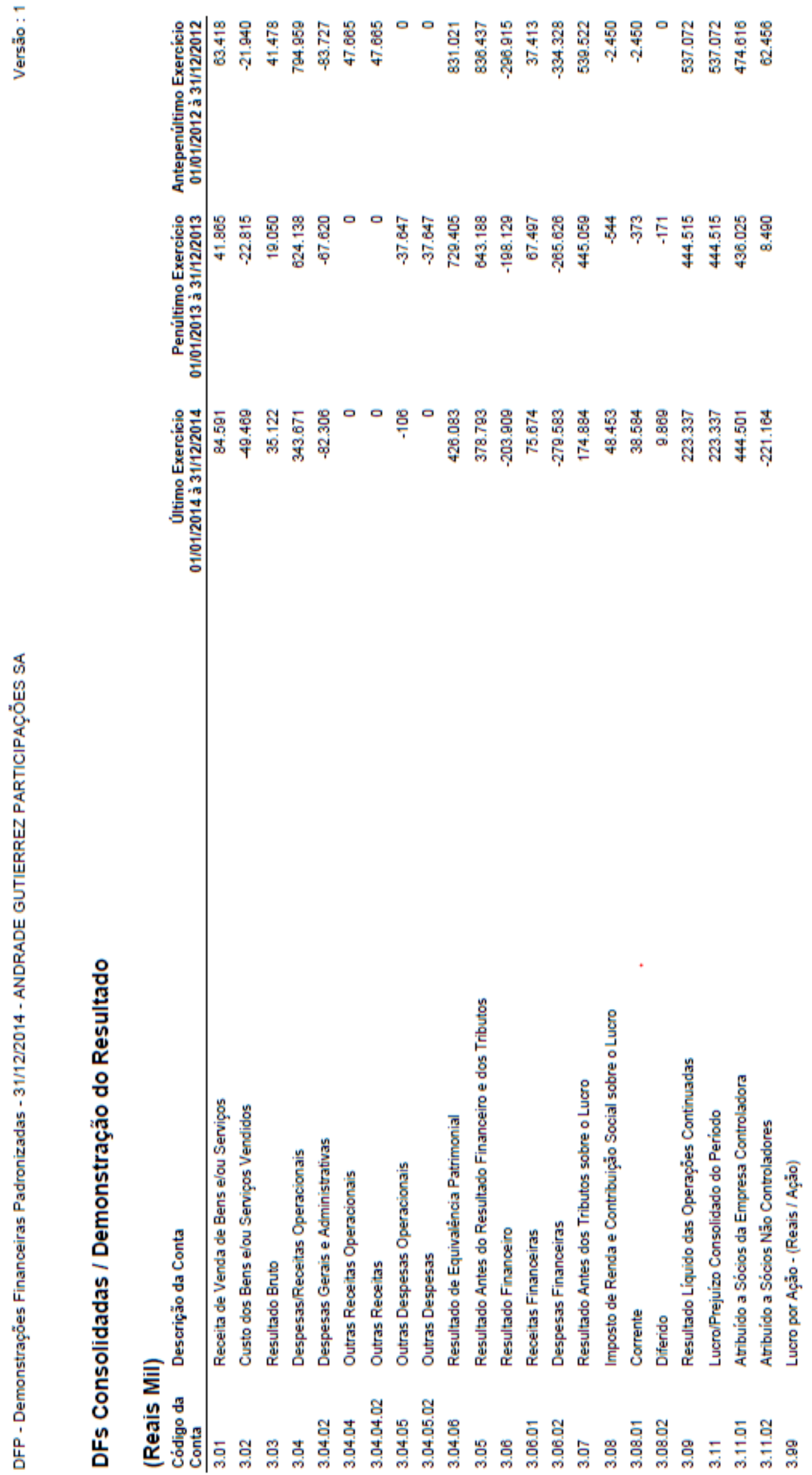


7.3. Balanço Patrimonial Andrade Gutierrez 2015, 2016 e 2017

高

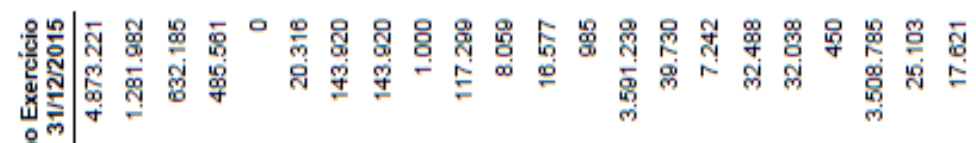

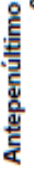

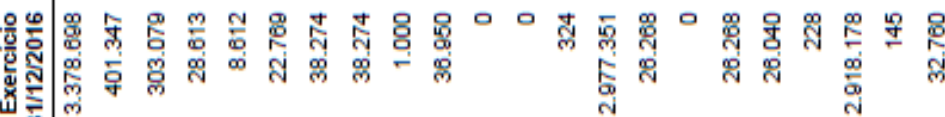

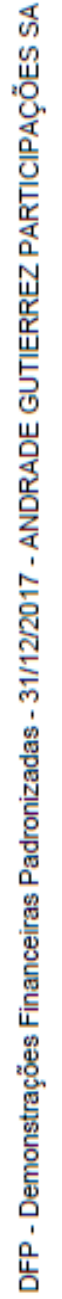

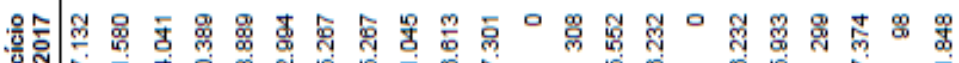

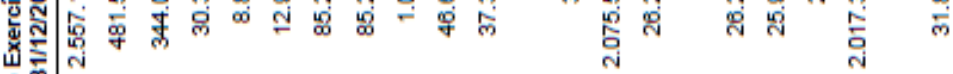

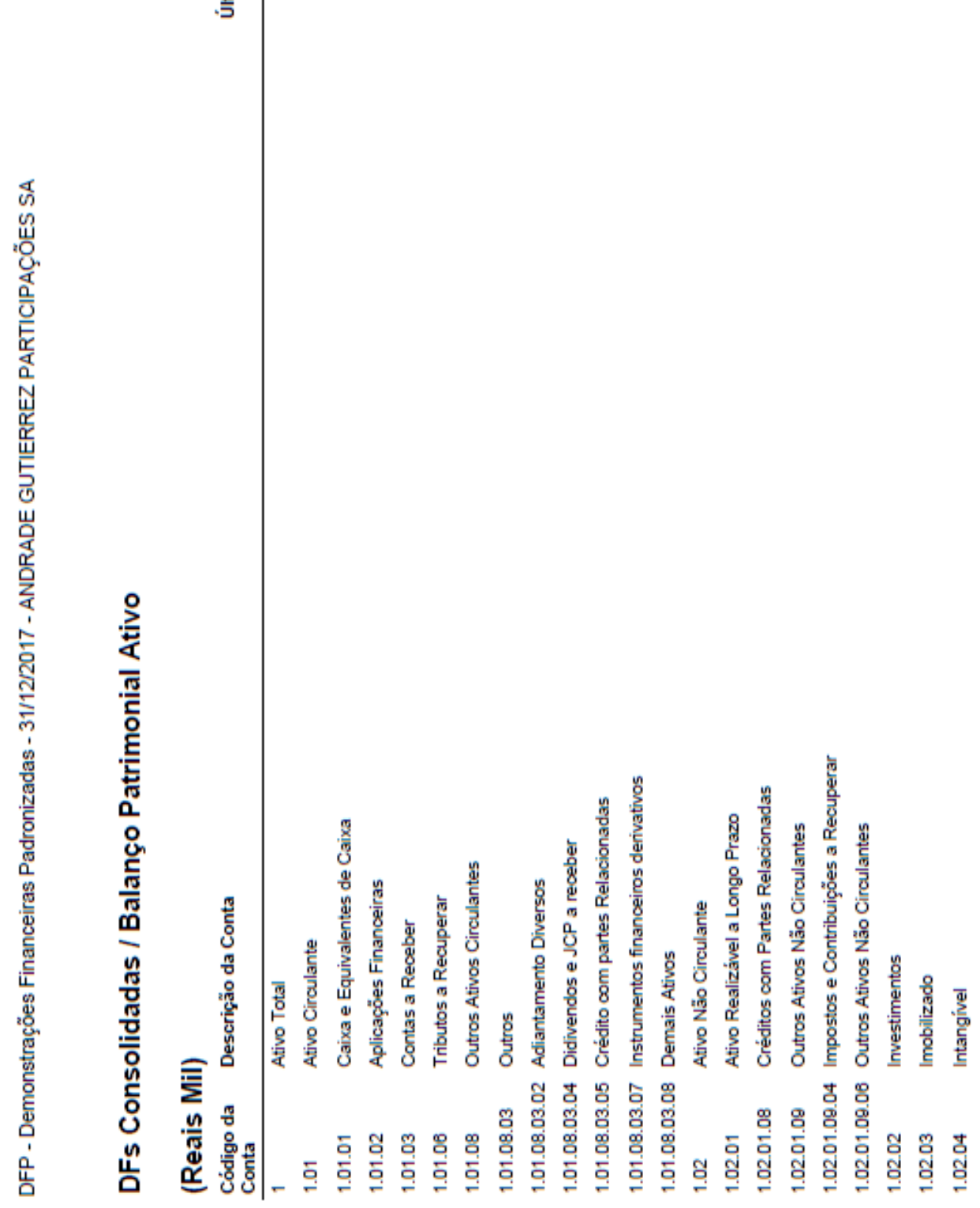




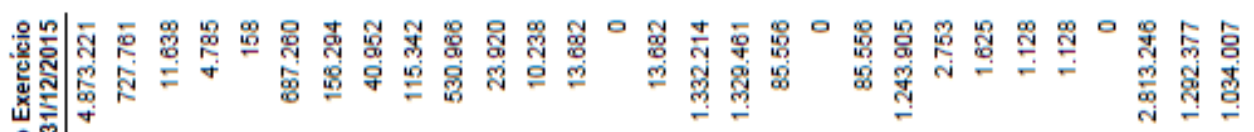
高

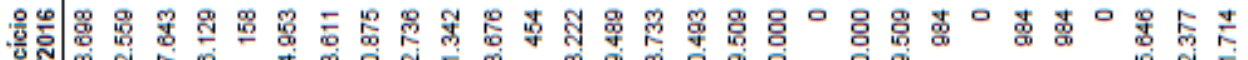

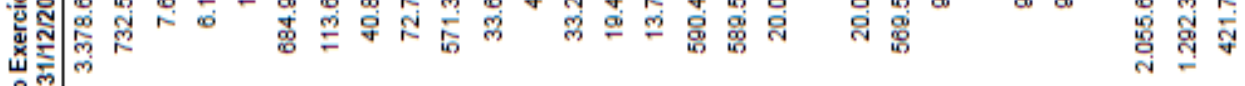
言

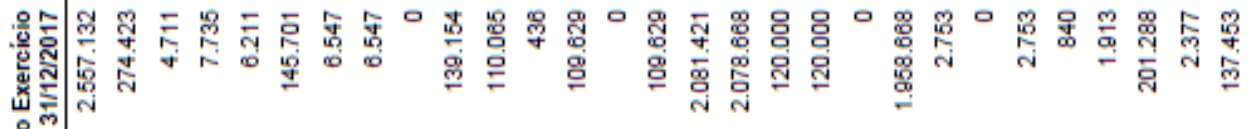




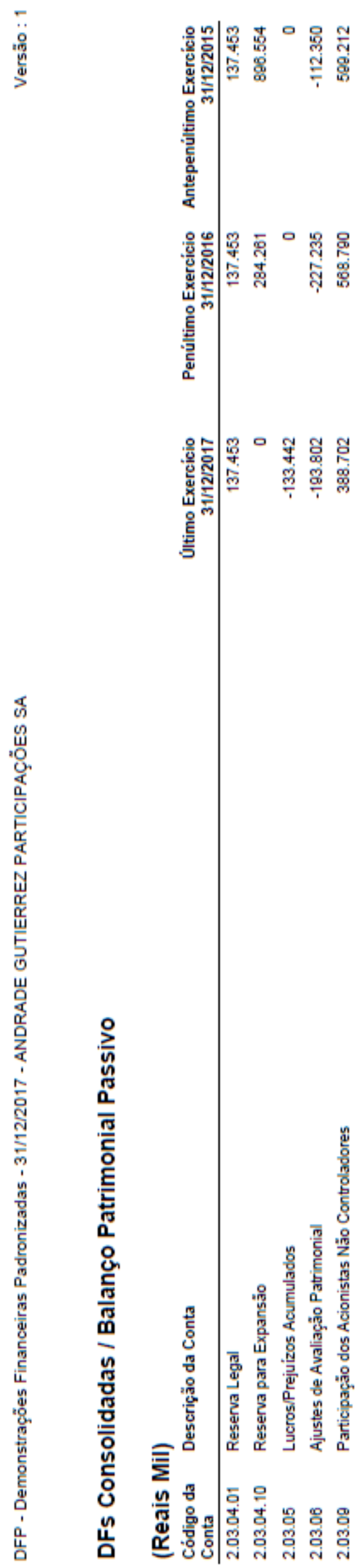


7.4. DRE Andrade Gutierrez 2015, 2016 e 2017

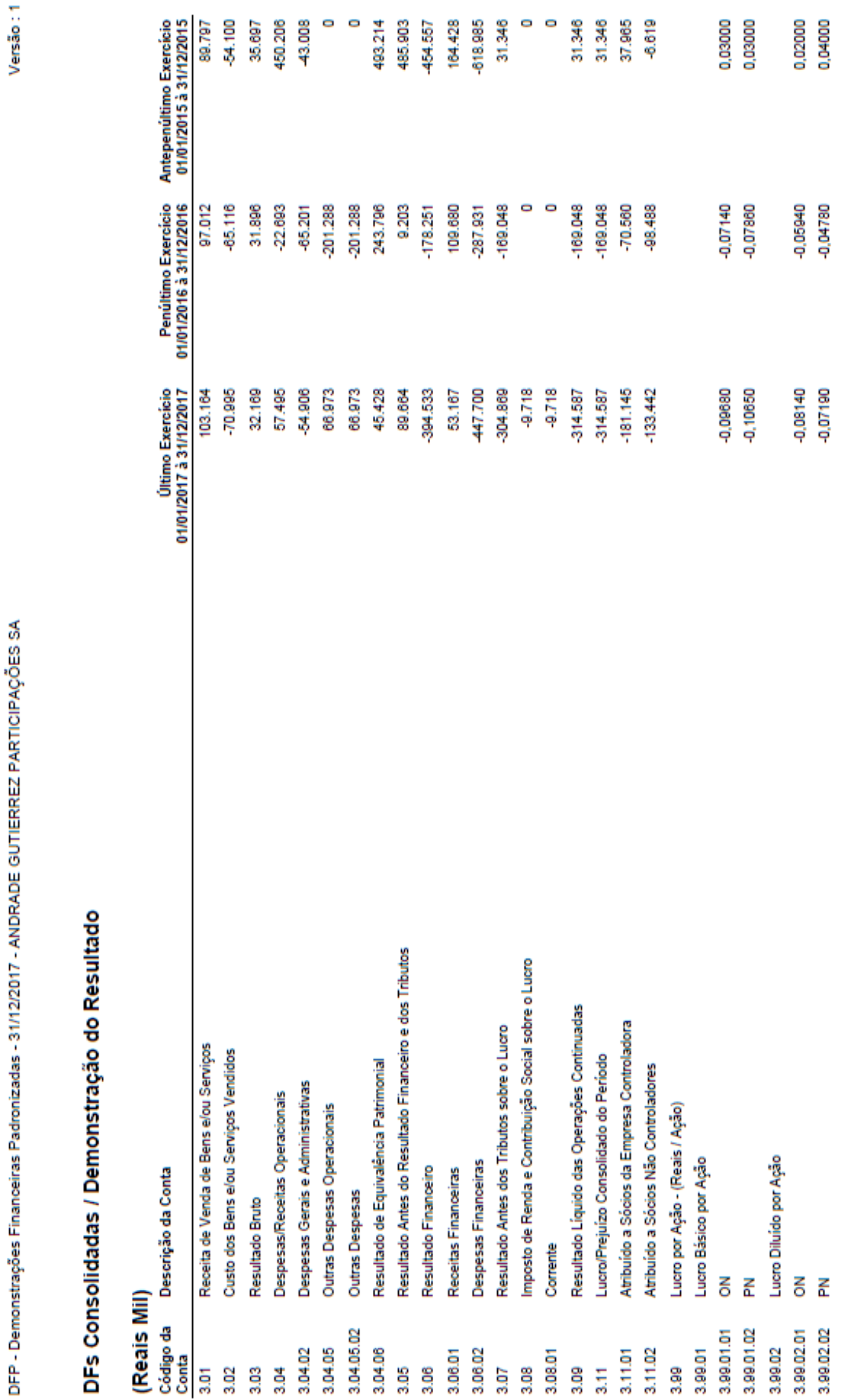


7.5. Balanço Patrimonial Queiroz Galvão 2012 e 2013

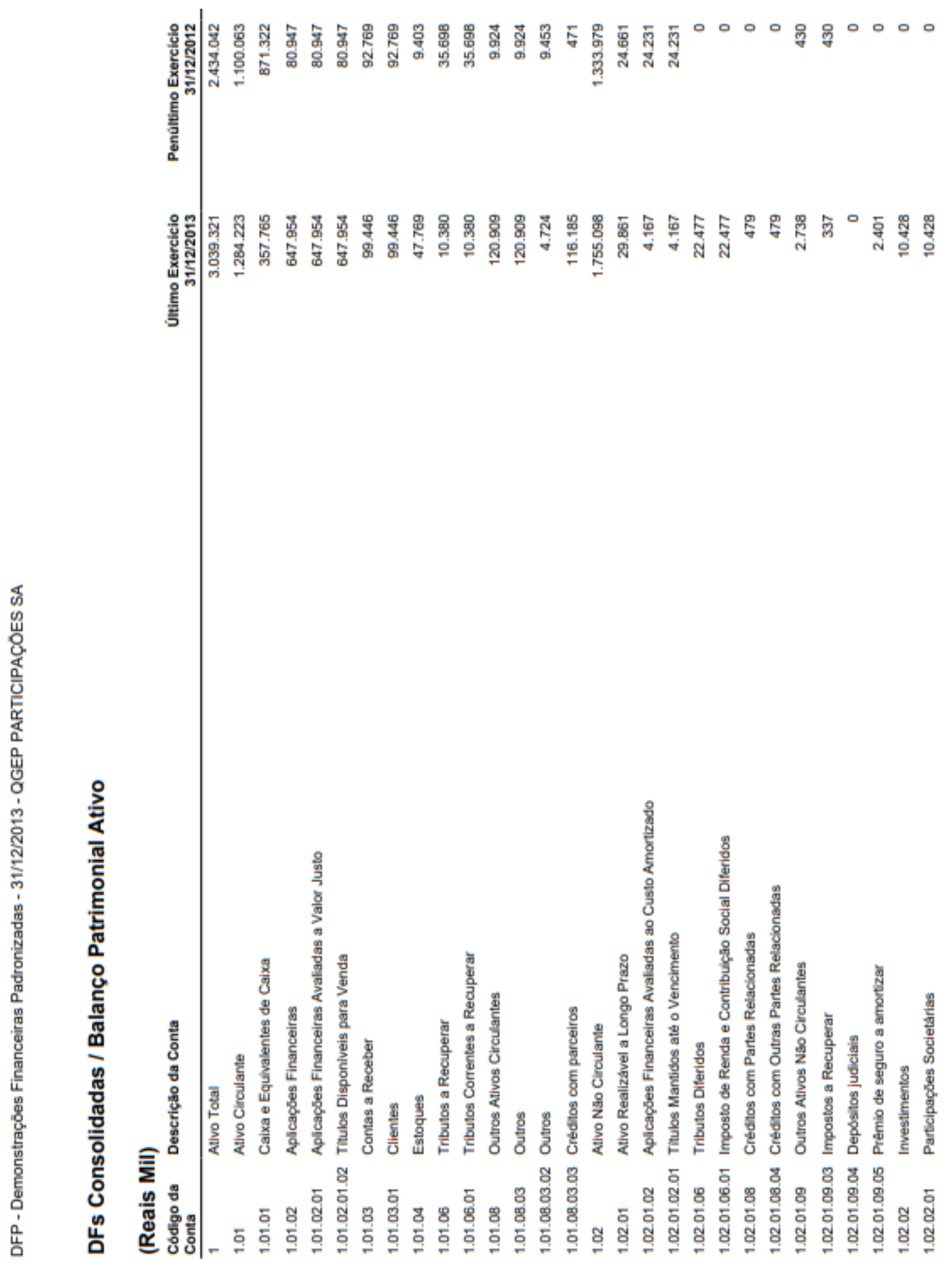


43

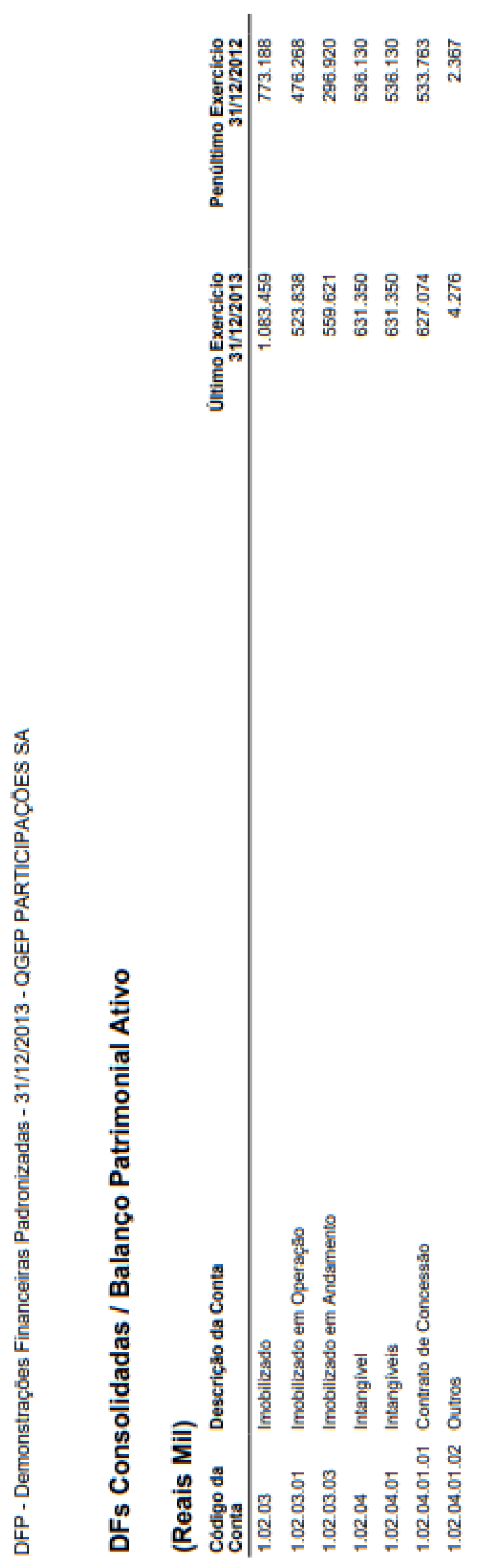




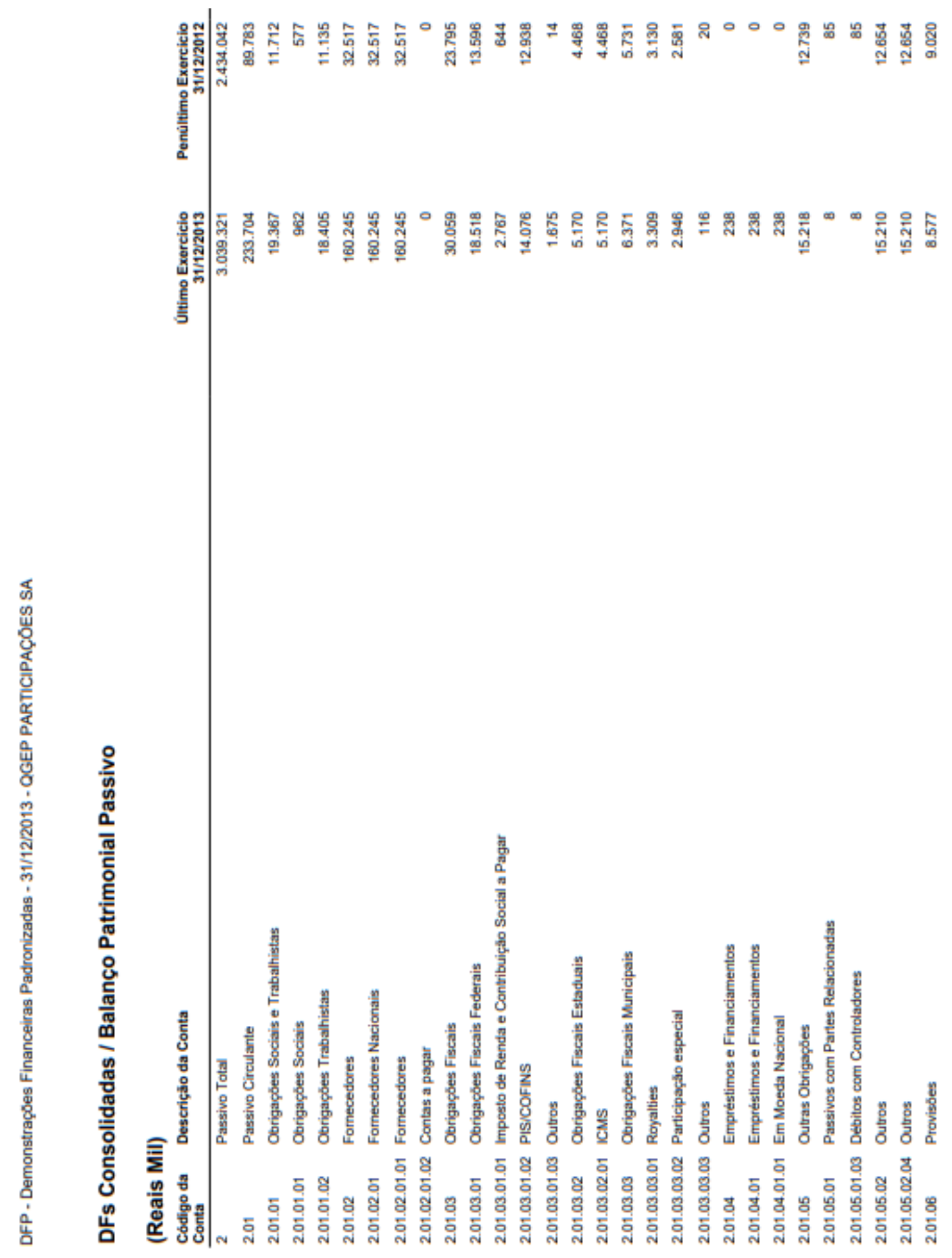




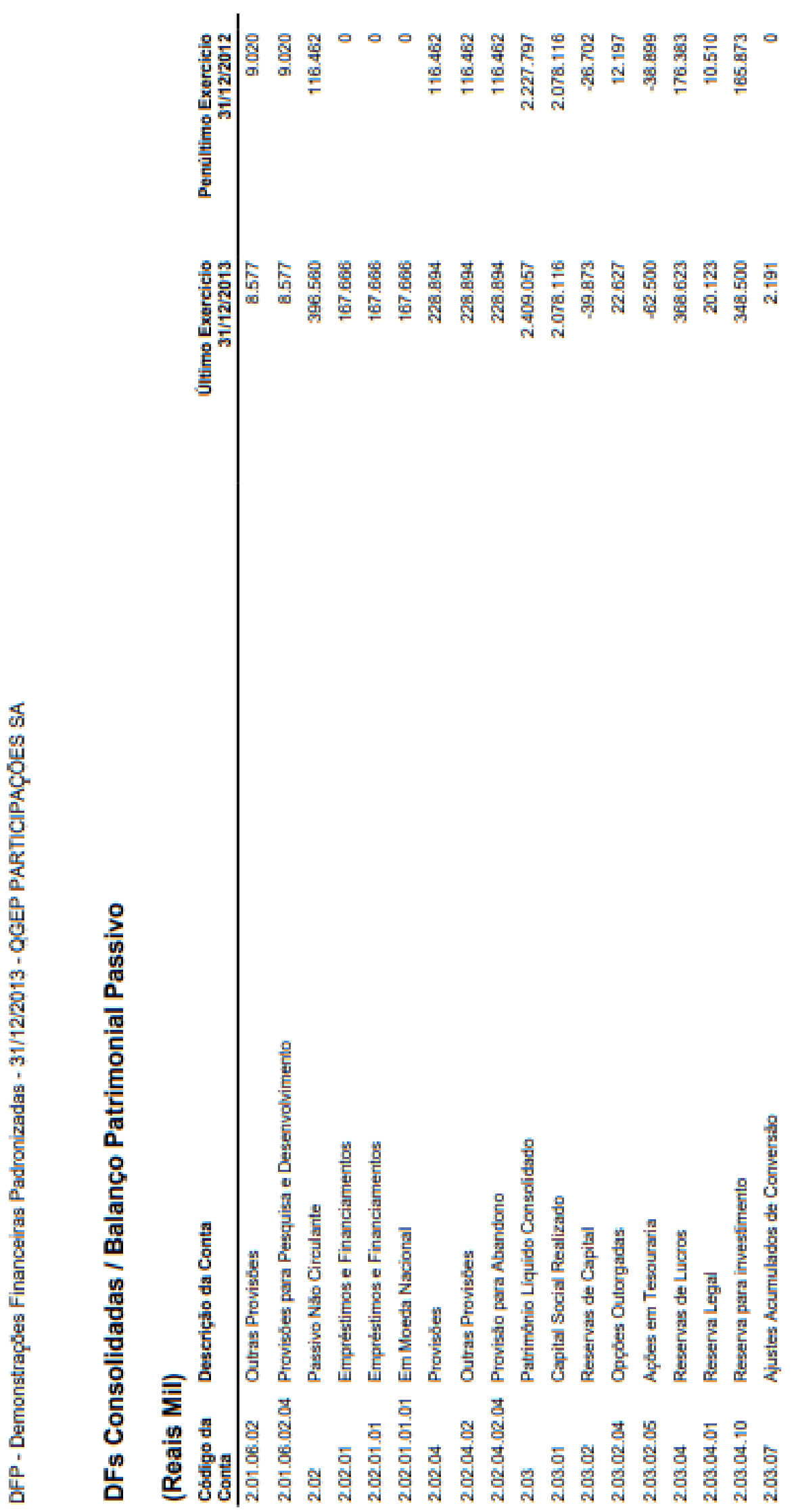


7.6. DRE Queiroz Galvão 2012 e 2013

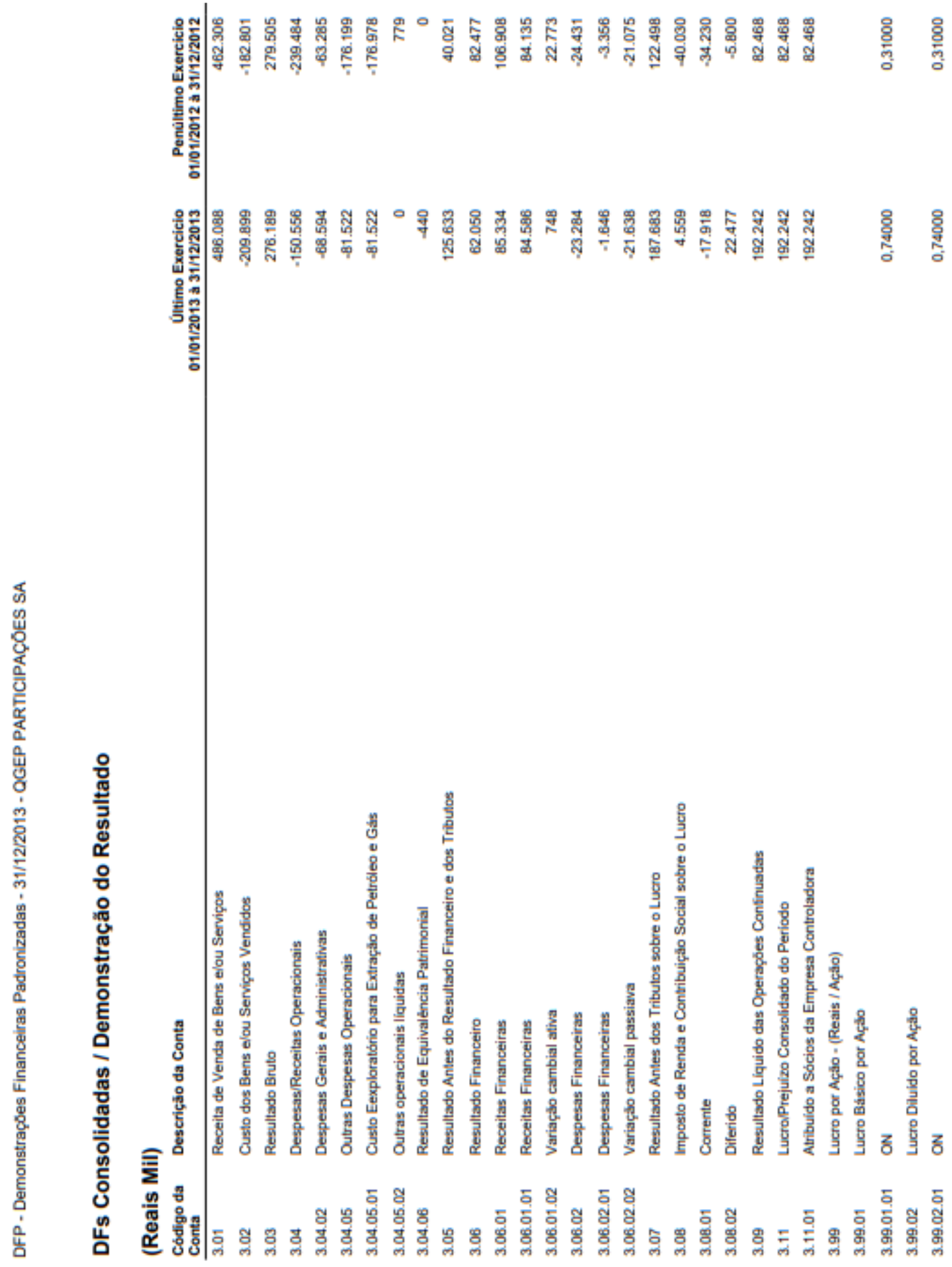




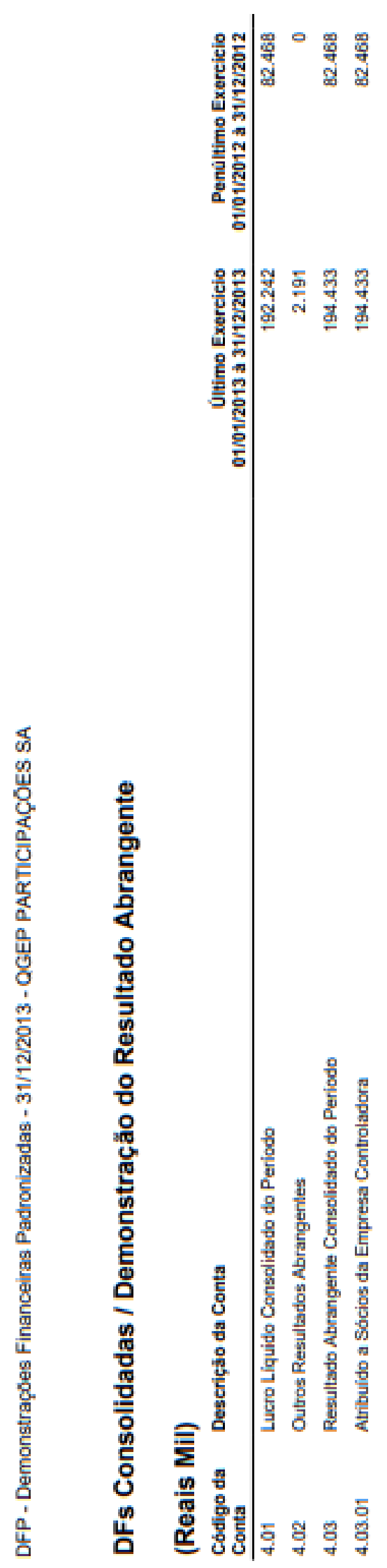

